\title{
HYDROLOGY AND EFFECTS OF MINING IN THE UPPER RUSSELL FORK BASIN, BUCHANAN AND DICKENSON COUNTIES, VIRGINIA
}

By J.D. Larson and John D. Powell

U.S. GEOLOGICAL SURVEY

Water-Resources Investigations Report 85-4238

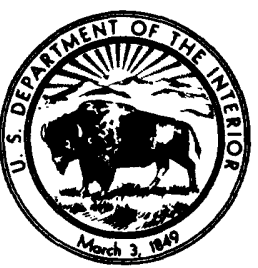

Richmond, Virginia

1986 
UNITED STATES DEPARTMENT OF THE INTERIOR

DONALD PAUL HODEL, Secretary

GEOLOGICAL SURVEY

Dallas L. Peck, Director

For sale by the Distribution Branch, U.S. Geological Survey, 604 South Pickett Street, Alexandria, VA 22304 


\section{ACKNOWLEDGMENTS}

Personnel from several mining companies provided data and advice to the authors in the course of the study. Special thanks is given to personnel of United Coal Company, Jewell Smokeless Coal Company, and Island Creek Coal Company for providing well information, maps, and access to core-hole data. Noah Horn Drilling Company, Keen Mountain Drilling Company, and Barton Drilling Company also provided well information. James Henderson, Jeremy Grantham, Martin Mitche11, Michael Morris, and Jack Nolde of the Virginia Division of Mineral Resources provided geologic information. John Plerce, Mike Dale, and Lynn Haynes of the Virginia Division of Mine Land Reclamation provided files on mine permits, water-quality data, maps, and well and spring information. The authors thank the people of Buchanan County who allowed access to their property, wells, and springs.

Personnel of the Virginia office of the U.S. Geological Survey deserve special recognition. James Gemme11, Curtis Barrett, and Peter Hufschmidt assisted in the collection of the streamflow, water-quality, and well data and assisted in aquifer testing. Richard Ahlin assisted the authors in data reduction and analysis. 
FACTORS FOR CONVERTING INCH-POUND ONITS

TO INTERNATIONAL SYSTEM (SI) UNITS

The following factors may be used to convert the inch-pound units published herein to the International System of Units (SI):

Multiply inch-pound units

by

To obtain SI units

\section{Length}

inch (in.)

foot $(\mathrm{ft})$

25.40

0.3048

mile (mi)

1.609

millimeter (mm)

meter (m)

kilometer (km)

\section{Area}

square $\mathrm{mile}\left(\mathrm{mi}^{2}\right)$

2.590

square kilometer $\left(\mathrm{km}^{2}\right)$

\section{Volume}

$\begin{array}{lll}\text { gallon (gal) } & 3.785 & \text { liter }(L) \\ \text { gallon (gal) } & 0.003785 & \left.\text { cubic meter (m }{ }^{3}\right)\end{array}$

\section{F1ow}

cubic foot per second $\left(\mathrm{ft}^{3} / \mathrm{s}\right) \quad 0.02832 \quad$ cublc meter per second

cubic foot per second per square mile

$\left[\left(\mathrm{ft} \mathrm{t}^{3} / \mathrm{s}\right) / \mathrm{mi}^{2}\right]$

gallon per minute (ga1/min)

0.01093 cubic meter per second per square kilometer $\left[\left(\mathrm{m}^{3} / \mathrm{s}\right) / \mathrm{km}^{2}\right]$

0.06308 11ter per second (L/s)

\section{Transmissivity}

foot squared per day $\left(f t^{2} / d\right)$

$$
0.09290
$$

meter squared per day $\left(\mathrm{m}^{2} / \mathrm{d}\right)$ 


\section{TABLE OF COLIBEITS}

ACKNOWLEDGMENTS. . . . . . . . . . . . . . . . . . . . . . . . . . . .

FACTORS FOR CONVERTING INCH-POUND UNITS TO IMTERHATIORAL SYSTEM

(SI) UNITS.

ABSTRACT.$\ldots \ldots \ldots \ldots \ldots \ldots \ldots \ldots \ldots \ldots \ldots \ldots \ldots \ldots \ldots \ldots \ldots \ldots \ldots \ldots \ldots \ldots \ldots \ldots$

1.0 INTROdUCTION. ....................................... 1

1.1 Purpose, scope, and methods of study................... 2

1.2 Location of area.................................... 4

2.0 GEOLOGIC SETTING................................. 7

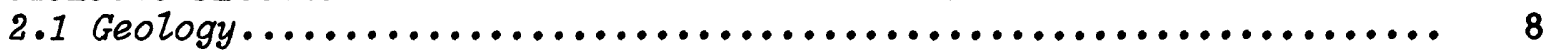

2.2 Linear features...................................... 10

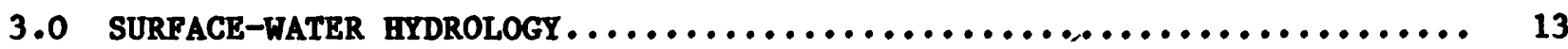

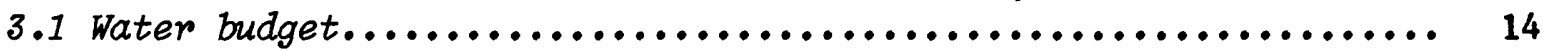

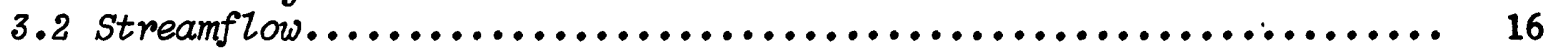

3.2.1 Correlation between gaged and ungaged sites........... 16

3.2 .2 Flow duration................................. 18

3.2 .3 Flow recession............................... 20

4.0 GROUND-WATER HYDROLOGT................................. 23

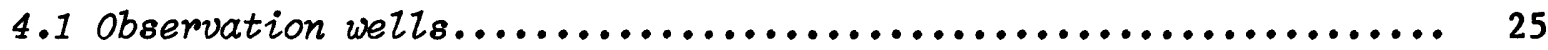

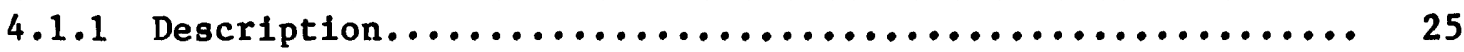

4.1 .2 Water-1evel fluctuations......................... 29

4.2 Aquifer hydraulic properties......................... 33

4.2 .1 Aquifer tests of valley wells.................... 33

4.2 .2 Aquifer tests of ridgetop wells................... 36

4.2.3 Aquifer properties from streamflow................. 38

4.3 Conceptual ground-water flow system................... 40

5.0 WATER QUALITY...................................... 43

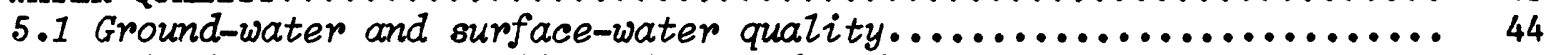

5.2 Relation between quality of ground and surface water........... 46

6.0 HYDROLOGIC BPFECTS OF MINING............................ 49

6.1 Effects of mining on surface water...................... 50

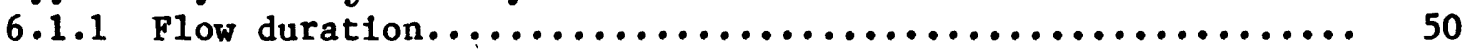

6.1 .2 Streamflow recession.......................... 52

6.1 .3 Diffusivity................................ 54

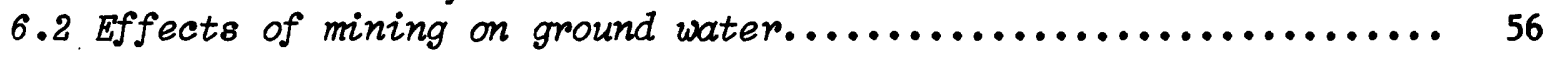

7.0 SUMMARY ANd conclusions............................. 59

8.0 SELECTED REFERENCES $\ldots \ldots \ldots \ldots \ldots \ldots \ldots \ldots \ldots \ldots \ldots \ldots \ldots \ldots \ldots \ldots \ldots \ldots \ldots \ldots \ldots \ldots$ 


\section{LIST OF ILLUSTRATIONS}

Figure

1.1-1

Map showing physiographic provinces and location of upper Russell

Page

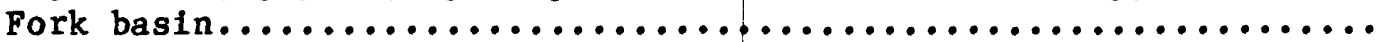

1.2-1 Map showing study area and location of data-collection sites......

2.1-1 Section across upper Russell Fork basin showing stratigraphic positions of sandstone, siltstone, shale, and major coal beds.....

$2 \cdot 2-1$ Map showing major linear features in upper Russell Fork basin.....

3.1-1 Graph showing base-flow and total runoff from the Russell Fork basin, 1971-1980, 1982 and 11-year average...................

3.1-2 Graph showing average monthly base flow and total runoff from the Russel1 Fork basin, 1971-1980, and 1982...................

3.2.1-1 Graph of streamflow correlation of Russell Fork at Hays1, Va. and Hurricane Creek................................... 17

3.2.3-1 Streamflow hydrograph for Barton Fork near Council, Va. showing recessions.......................................

4.1.1-1 Diagram showing construction features and location of observation

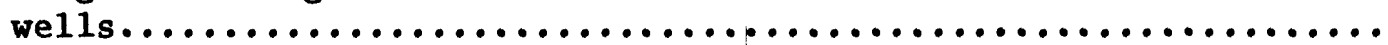

4.1.2-1 Graphs showing water-level fluctuation in observation wells and

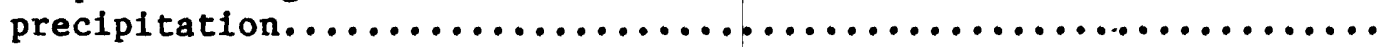

4.2.1-1 Graph showing aquifer-test analysis for valley wells by straight-

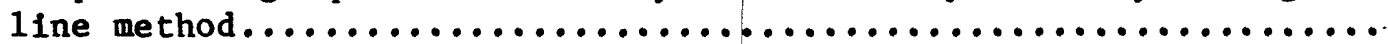

4.2.1-2 Graph showing aquifer-test analysis for valley wells by typecurve method........................................

4.2.2-1 Graphs of slug-test results from ridgetop wells and type curves

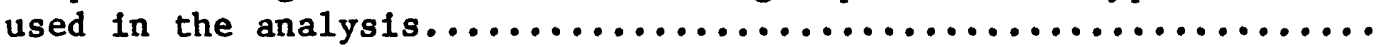

4.2.3-1 Graph of streamflow hydrograph for Grissom Creek showing a

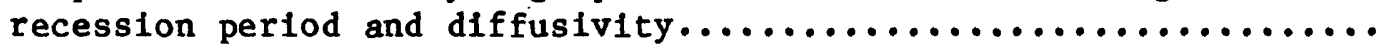

$4 \cdot 3-1$ Diagram showing conceptual ground-water flow system in the study area..............................................

5.1-1 Trilinear diagram showing ground-water and surface-water quality in the Grissom Creek and Barton Fork basins..................

5.2-1 Scatter diagram showing comparison of calcium and sodium activities for we11, spring, and stream water in Grissom Creek basin ..............................................

6.1.1-1 Graph of flow duration curves for Russell Fork and Clinch River...

6.1.2-1 Graph showing composite winter recessions before and after 1950 for Russe11 Fork at Haysi, Va..........................

Graph showing streamflow recessions for Russell Fork at Haysi,

6.1.3-1 Graph showing relation of diffusivity to extent of surface mining in the upper Russell Fork basin.......................... 


\section{TABLES}

- Table

3.2.2-1

Estimated streamflow statistics for 28 miscellaneous

Page

measurement. sites in the upper Russell Fork basin......... 19

4.2.1-1 Aquifer test data for valley material................. 34

6.1.3-1 Selected physical and hydraulic characteristics of basins above five gaging stations in the Russell Fork basin........ 55 
HYDROLOGY AND EFFECTS OF MINING IN THE UPPER RUSSELL FORK BASIN, BUCHANAN AND DICKENSON COUNTIES, VIRGINIA

By J. D. Larson and John D. Powel1

\begin{abstract}
Aquifer transmissivities estimated from pumping and slug tests at six observation wells in the Russell Fork basin decrease greatly with depth. Transmissivities also differ significantly between ridgetop and valley settings. Transmissivity ( $T$ ) values at a ridge site range from about 0.30 feet squared per day $(\mathrm{ft} / \mathrm{d}$ ) near land surface to about $0.008 \mathrm{ft}^{2} / \mathrm{d}$ at a depth of 500 feet. $T$ values in valley wells ranged from about $270 \mathrm{ft}^{2} / \mathrm{d}$ in alluvial material to about $0.15 \mathrm{ft}^{2} / \mathrm{d}$ in unweathered material below a depth of 60 feet. Estimated storagecoefficient (S) values of 0.00040 and 0.00048 were obtained from a weathered rock zone between 14 and 60 feet below land surface in a valley well. Aquifer tests suggest that the major aquifer system in the Russell Fork basin consists of the alluvial material and a veneer of weathered and highly fractured rock in the basin.

Flow-duration statistics obtained from a stream gage at Haysi, Virginia indicate a change in flow at the 95-percent exceedence leve1 since the start of surface mining; flow increased from 4.0 (1928-50) to 8.9 cubic feet per second (1951-80).

Base-flow recessions for the Russell Fork at Haysi stream gage indicate a change in ground-water depletion rate from 34 to 59 days per log cycle of discharge for the pre-1950 (0-percent mined) to the post-1950 (5-percent mined) period. This change produced a change in diffusivity from 28,500 $\mathrm{ft}^{2} / \mathrm{d}$ (pre-1950, negligible surface mining) to $16,500 \mathrm{ft}^{2} / \mathrm{d}$ (post-1950, 5 percent of basin mined). Based on analysis of individual recessions for five gaging stations, diffusivity ranges from $28,500 \mathrm{ft}^{2} / \mathrm{d}$ for Russell Fork at Haysi before mining, to 10,100 $f t^{2} / \mathrm{d}$ for Barton Fork near Councll, Virginia, which has 19.5 percent of its area disturbed by surface mining.
\end{abstract}


1.0 INTRODUCTION 


\subsection{Purpose, Scope, and Methods of Study}

Evaluating The Impacts Of Surface Coal Mining ON The Water RESOURCES OF AN AREA REQUires AN UNDERSTANDING OF THE HYDROLOgIC FramewORK.

Hydrologic data from the upper Russell Fork basin provide information for development of a conceptual model of the local flow system and the hydrologic framework. Groundwater levels, water-quality data, precipitation data, streamflow data, and selected basin characteristics are used to define the total hydrologic system in the upper Russell Fork basin.

Petroleum shortages in the early 1970 's produced an upsurge in coa1 production as an alternative source of energy. These production increases occurred simultaneously with changes in environmental regulations governing mining activities. Industry and regulatory agencies need to know both the local hydrologic framework and basic hydrologic concepts in order to understand the natural and man-made factors affecting the hydrologic system.

This report presents the results of a study of the upper Russell Fork basin of the Appalachian Plateau Province (fig. 1.1-1)--a typical coal-area basin. The report (1) describes the ground-water and surface-water hydrology and water quality in a river basin draining a coal-producing area in southwestern Virginia; (2) describes the effects of mining on the hydrologic system; and (3) provides a conceptual understanding of the hydrologic system.

Ground-water levels, aquifer tests, water-quality data, precipitation data, and streamflow data (preand post-mining), are evaluated in order to understand the hydrologic system and possible impacts of surface mining. Methods of determining aquifer properties from streamflows are shown.

The Virginia Division of Mineral Resources, as part of this study, mapped the geology in the Prater and Vansant quadrangles to complete the geologic framework for the area. Virginia Polytechnic Institute and State University, Department of Fisheries, provided data on basin characteristics. Field studies began in December of 1980. Eight observation wells were drilled (JuneOctober 1981) and four gaging stations were constructed (Ju1y 1981). Data for the observation wells and short-term gaging stations are analyzed for October 1981 through September 1982. Records for the Russel1 Fork gaging station at Haysi are analyzed for 1926 to 1982. Discharge and water-quality data were obtained at 28 surface-water sites. Streamflow, precipitation, and waterquality data for sites included in this report are pub1ished by the U.S. Geological Survey (1982), and groundwater quality is discussed (Rogers and Powe11, 1983). 


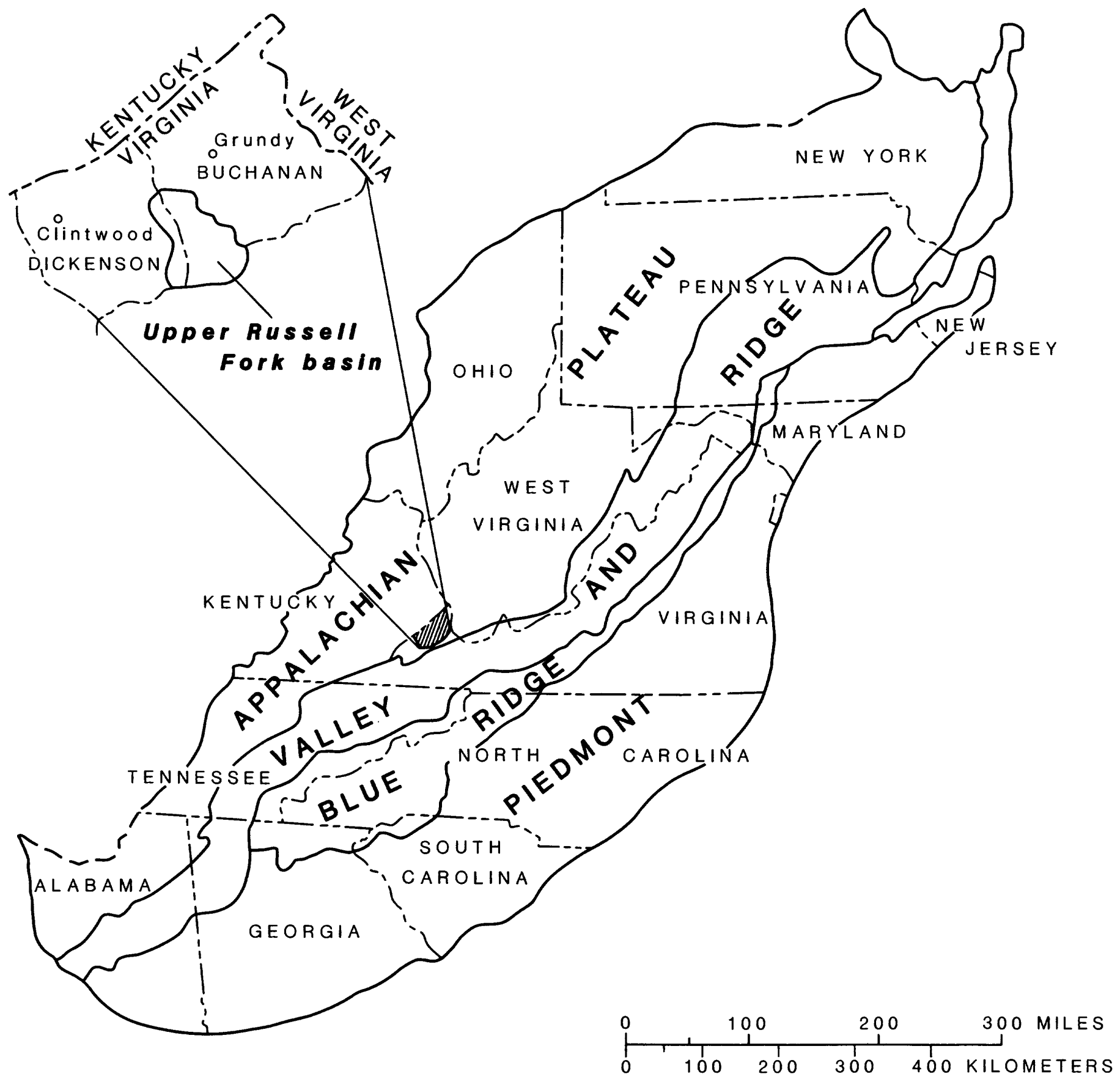

Figure 1.1-1 -- Physiographic provinces and location of upper Russell Fork basin. 
1.2 Location of Area

\title{
Upper Russell Fork Basin Represents a Typical Hydrogeologic
}

Setting In a Coal-Producing Area OF Virginia

\begin{abstract}
A part of the upper Russell Fork basin of Buchanan and Dickenson Counties, Virginia, was selected for study because it neets the criteria needed to evaluate the ground-water and surface-water hydrology of a river basin draining a coal-producing area in southwestern virginia.
\end{abstract}

The Russell Fork basin is located within Buchanan and Dickenson Counties in southwestern Virginia (f1g. 1.2-1). This drainage basin was selected for study because it is a typical hydrogeologic basin in a coal area and meets the criteria for evaluating ground-water and surface-water hydrology.

The criteria considered for selection of the study area were (1) avallablity of long-term streamflow data (USGS gaging station 03208500 at Haysi, 1926-present); (2) adequate data concerning geologic framework (access to recently drilled core holes); (3) mixture of mined and unmined subbasins ( 0 to 56 percent of basin areas disturbed by surface mining); (4) geologic and topographic similarity to other stream basins in the coal-producing area of southwestern Virginia; and (5) low population density.

The dratnage area of the Russell Fork above the gaging station at Hays1, Virginia, is $286 \mathrm{ml}^{2}$ (square miles). Study emphasis was on the following subbasins: upper Russell Fork ( $86.5 \mathrm{mi}^{2}$ ) above the gaging station near Birchleaf; Russell Fork above the gaging station at Counc1l $\left(10.2 \mathrm{ml}^{2}\right)$, and detalled studies of Gr1ssom Creek (2.83 $\left.\mathrm{mt}^{2}\right)$ and Barton Fork $(1.23 \mathrm{~m} 12)$. Gaging-station locations, miscellaneous measurement sites, and two well-cluster sites are shown on figure 1.2-1. 


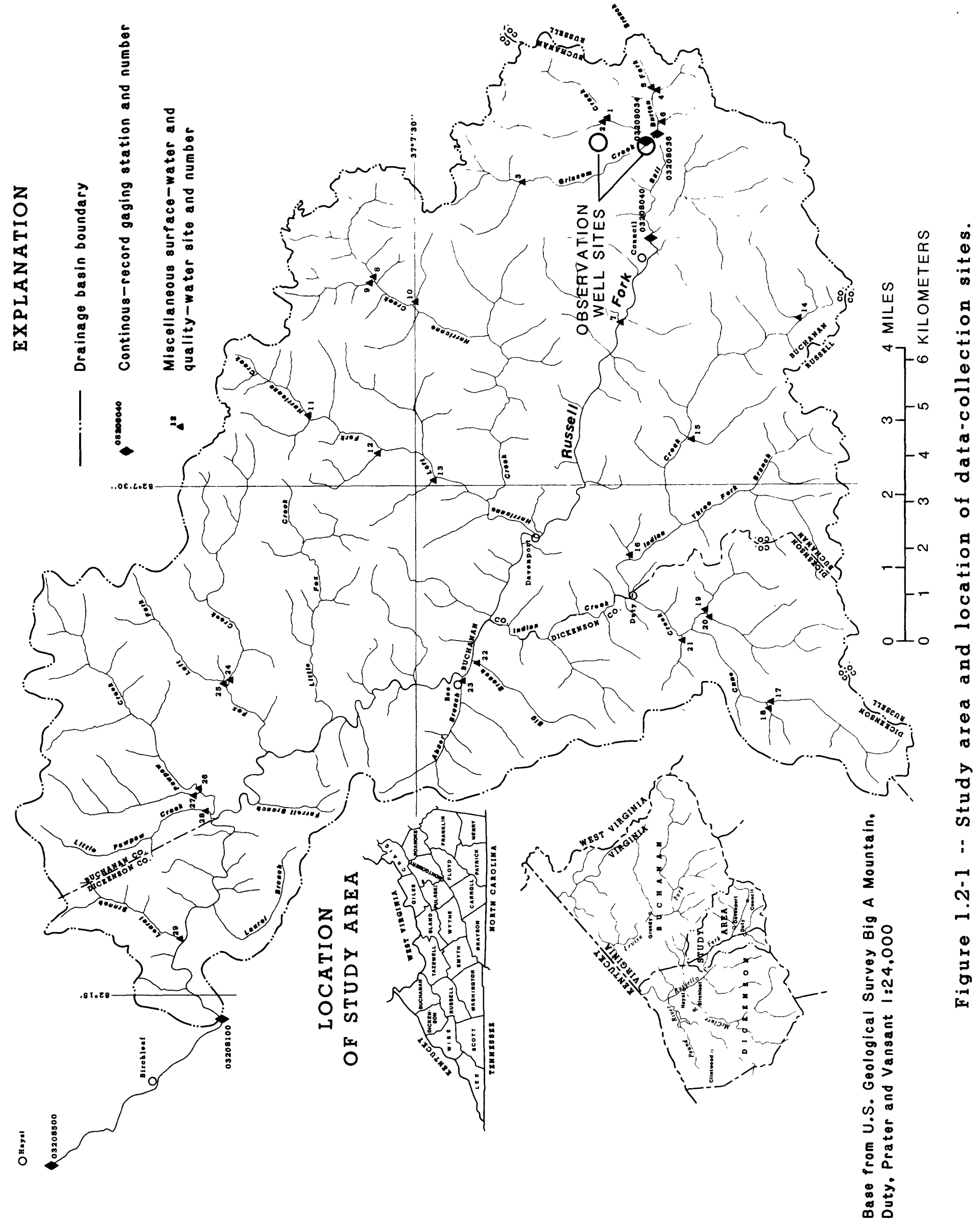

page 7 follows 
2.0 GEOLOGIC SETTING 


\subsection{GEOLOGIC SETTING}

\subsection{Geology}

\section{The Upper Russell Fork Basin Is UnderLain By Gently Dipping Beds Of Sandstone, Siltstone, And Coal}

The upper Russell Fork basin is underlain primarily by gently dipping beds of sandstone, siltstone, and coal of Early and Middle Pennsylvanian age. A small outlier of sedimentary rocks of Barly Cambrian to Barly Pennsylvanian age is exposed at the eastern edge of the basin. Holocene alluvium and co1luvium commonly overlie older rocks in valley bottoms and on hillsides.

Most rocks of the upper Russe11 Fork basin are included in the Norton Formation of Early and Middle Pennsylvanian age. This formation lies stratigraphically between the underlying Lower Pennsylvanian Bee Rock Sandstone Member of the Lee Formation, and the overlying Middle Pennsylvanian Gladeville Sandstone. The Norton Formation is predominantly sandstone (over 50 percent) in the study area with siltstone, shale, and coal beds comprising the remainder. Small outliers of Middle Pennsylvanian Wise Formation which overlie the Gladeville Sandstone are found on the higher ridgetops. Small outcrops of the underlying Lee Formation are found where extensive faulting has brought this formation to the surface. The oldest rocks exposed in the basin are Early Cambrian to Early Pennsylvanian age. These crop out on the eastern edge of the basin where the Appalachian Plateau Province is in contact with the adjoining Valley and Ridge Province. The youngest rock material present (Quaternary age) is alluvium in the valley bottoms and colluvium on hillsides. Thicknesses of these deposits range from 0 to 30 feet.

Figure 2.1-1 shows a geologic section across the northern part of the Russell Fork basin prepared by the Virginia Division of Mineral Resources. Rock identifications are based on samples from exploratory core holes. Strata dip gently to the northwest at about 50 feet per mile. 

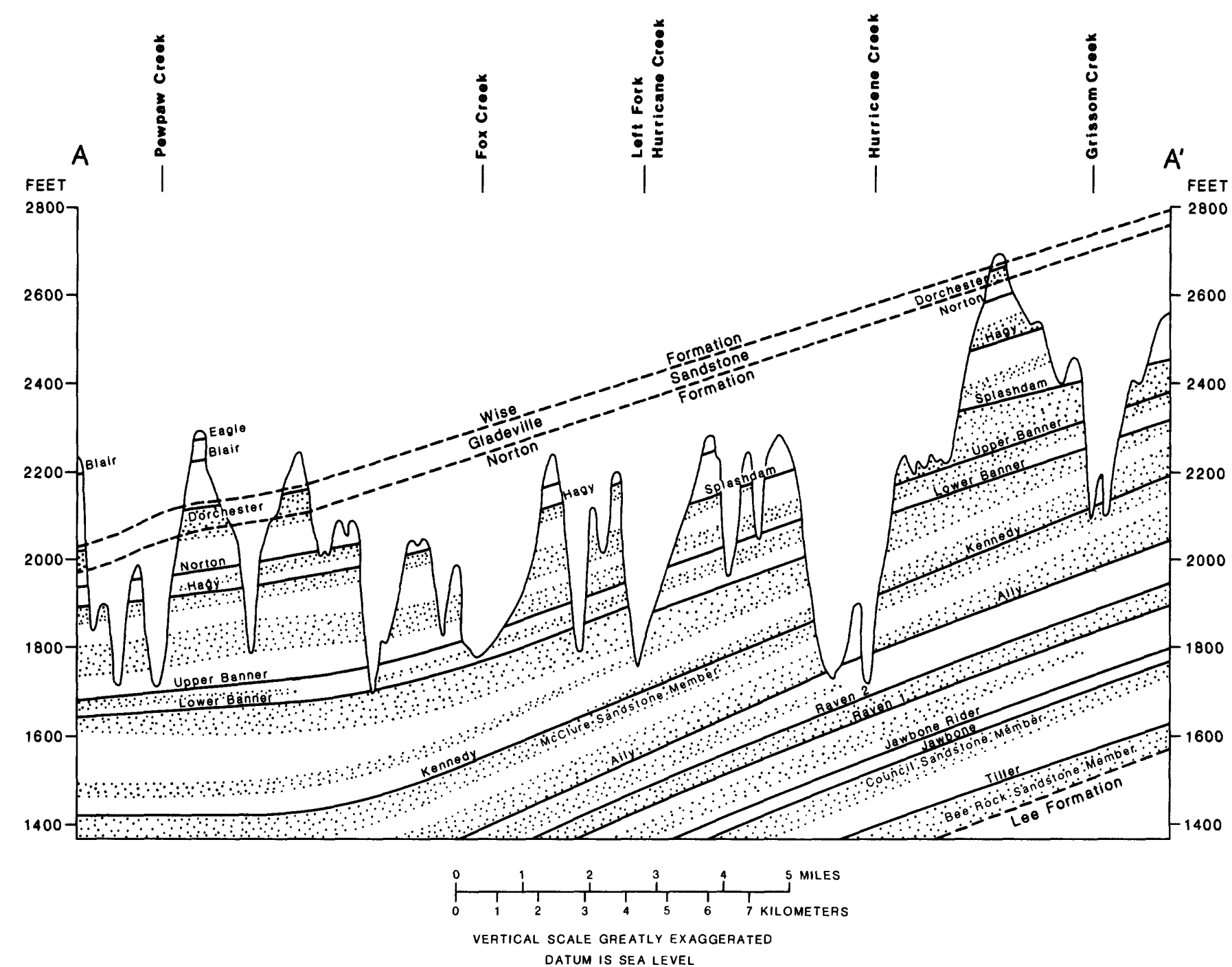

EXPLANATION

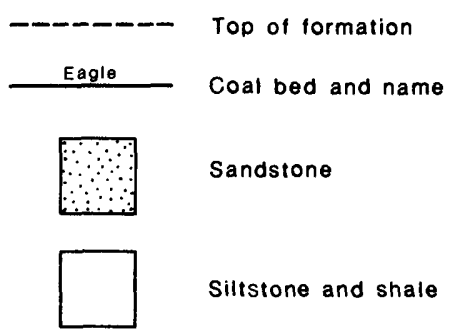

\section{LOCATION OF CROSS SECTION}

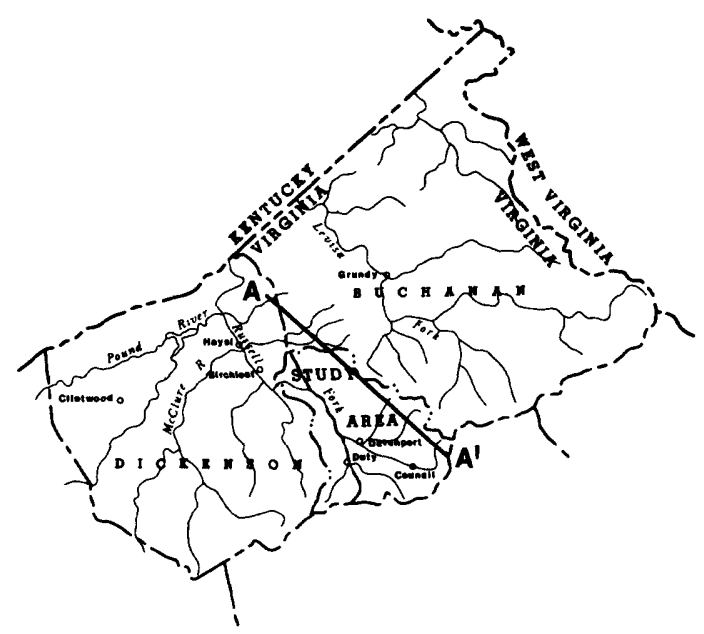

Figure 2.1-1 -- Section across upper Russell Fork basin showing stratigraphic positions of sandstone, siltstone, shale and major coal beds. 
2.0 GEQLOGIC SETTING (continued)

2.2 Linear Features

\section{Russell Fork Fault Is Major Linear \\ Feature In UPPER RUSSELl Fork Basin}

The Russell Fork Fault is the major linear feature in the upper Russell Fork basin. Additional linear features are present.

The major linear feature in the Russell Fork basin is the Russell Fork Fault (fig. 2.2-1). This feature extends southeastward from Bee, Virginia to the headwaters of the basin, parallel to the mainstream of the Russell Fork. It is a strikeslip fault with the northern section of the fault displaced about 4 miles to the east of the southern section
(Englund, 1971). The Virginia Division of Mineral Resources deIineated additional linear features within the basin as shown on the figure. Only the most prominent lineaments as seen from varlous high altitude and satellite photographs of the area are shown. Most tributary stream valleys appear as minor linear features. 


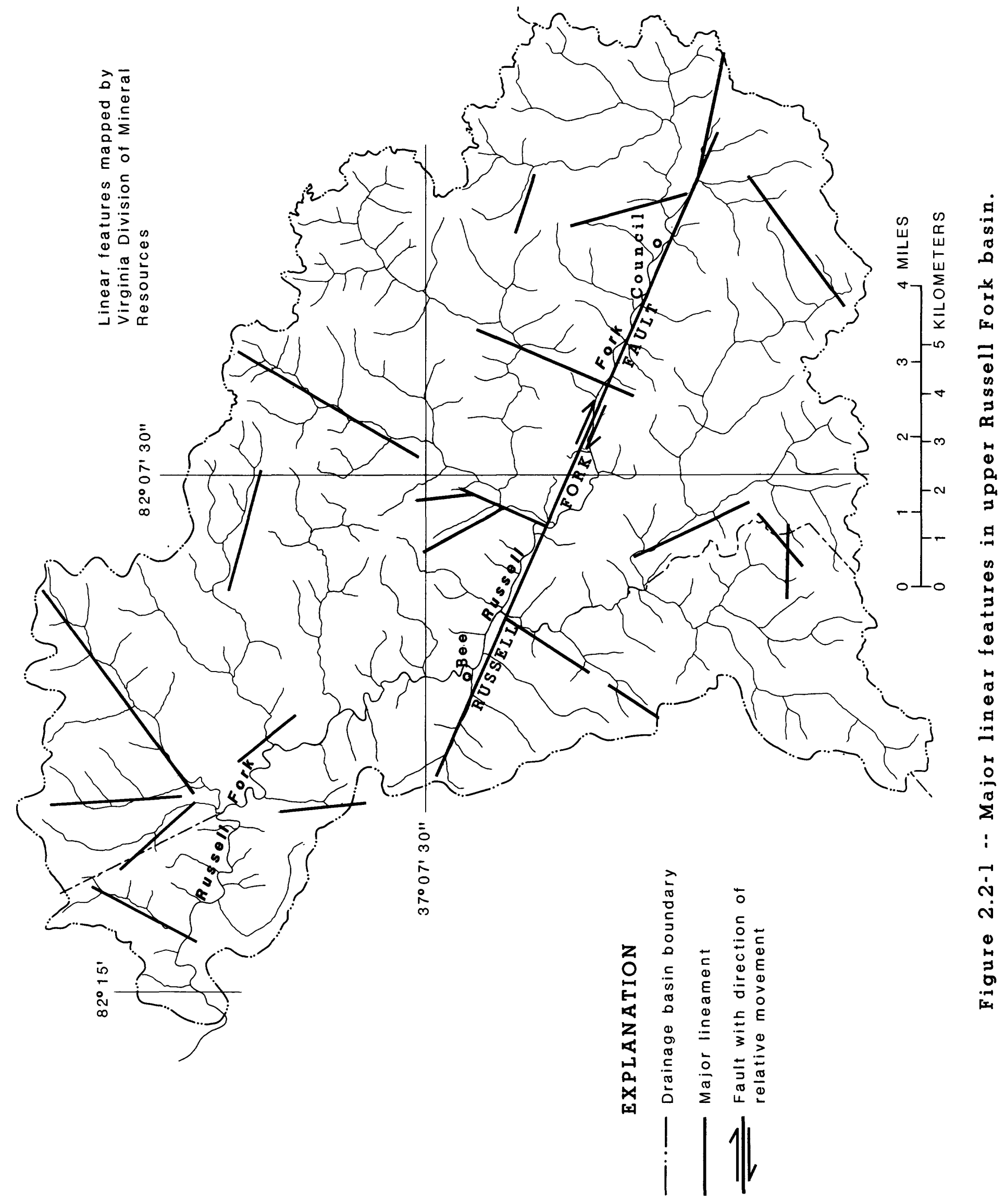


3.0 SURFACE-WATER HYDROLOGY 


\subsection{Water Budget}

A Water Budget Indicates That About ONe Third Of Total Runoff Is Ground-Water Discharge

Streamflow hydrographs for Russell Fork at Haysi were separated into direct runoff and base-flow for 1971-1980 and 1982. These separations indicate that about 35 percent of total runoff is derived from the ground-water system. Monthly averages Indicate that maximum runoff occurs in March, and ninimum runoff occurs in September for both runoff components. Based on the water budget, about 50 percent of precipitation evapotranspirates.

Total water gain and loss for a basin may be estimated using a water budget. Assuming that ground-water and surface-water divides coincide and that precipitation is the only source of water, a water budget may be stated as $P=Q+E$, where $P$ is precipitation, $Q$ is total basin runoff, and $E$ is evapotranspiration. This equation assumes no changes in groundwater and surface-water storage for several years of record. Precipltation averaged about 40 inches per year in 1971-1980 and 1982. Average streamflow at the Haysi gage represented about 19.5 inches of runoff per year; thus, 20.5 inches or about 50 percent of total prectpitation on the basin is lost to evapotranspiration.
The streamflow hydrograph for Russe11 Fork at Haysi, which measures total basin runoff above the gaging station, was subdivided by inspection Into direct overland runoff and baseflow runoff (ground-water discharge to the stream) for 1971-1980 and 1982. Figure 3.1-1 shows base flow and total runoff on an annual basis and the 11-year average. Figure 3.1-2 shows the average monthly values for base flow and total runoff for the same perlod of record. The average base-flow runoff for the 11year perlod was about 7 inches per year, which equals 35 percent of the 19.5 inches of total runoff per year. 


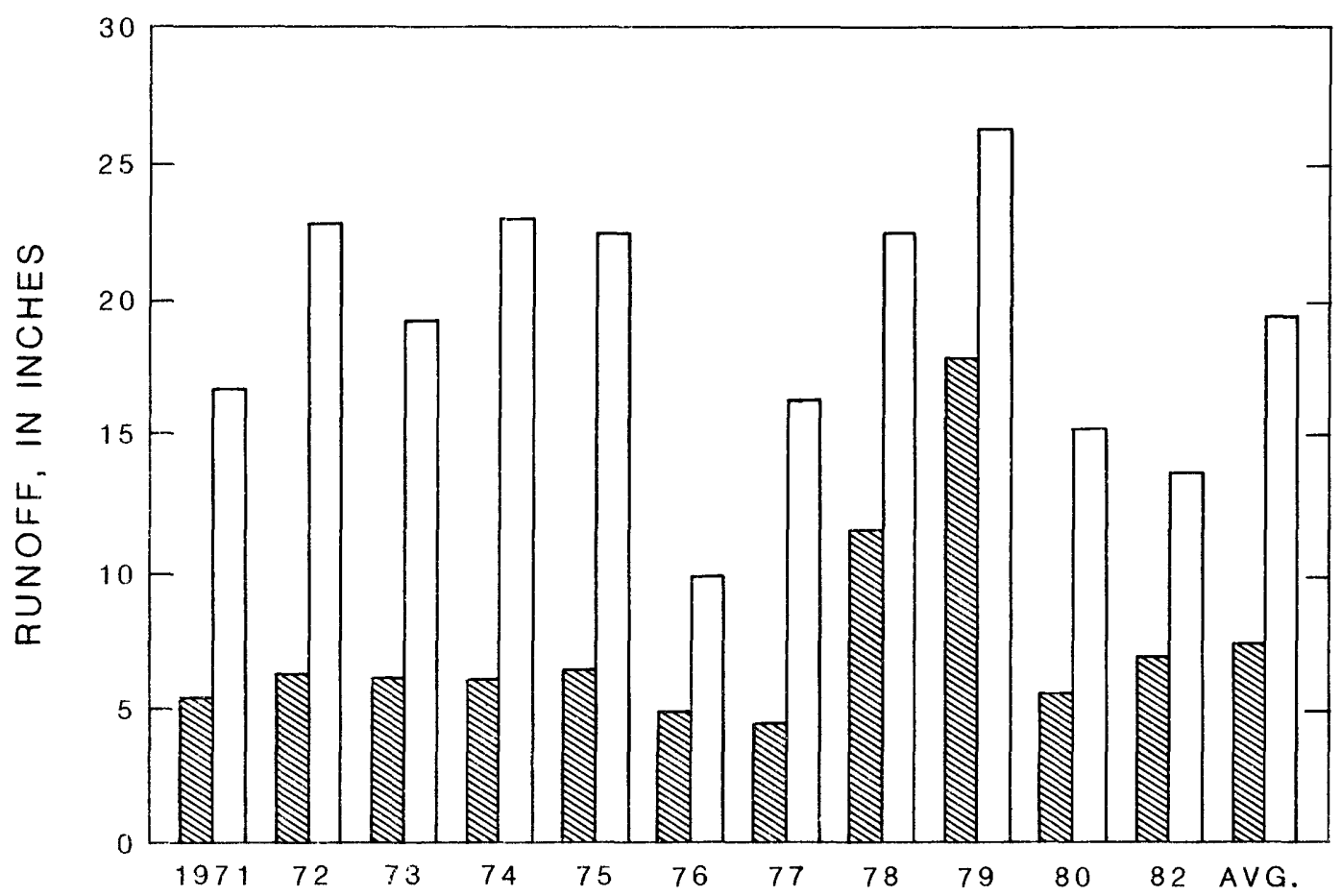

Base-flow runoff $\square$ Total runoff

Figure 3.1-1 -- Base flow and total runoff from the Russell Fork basin, 1971-80, 1982 and 11-year average.

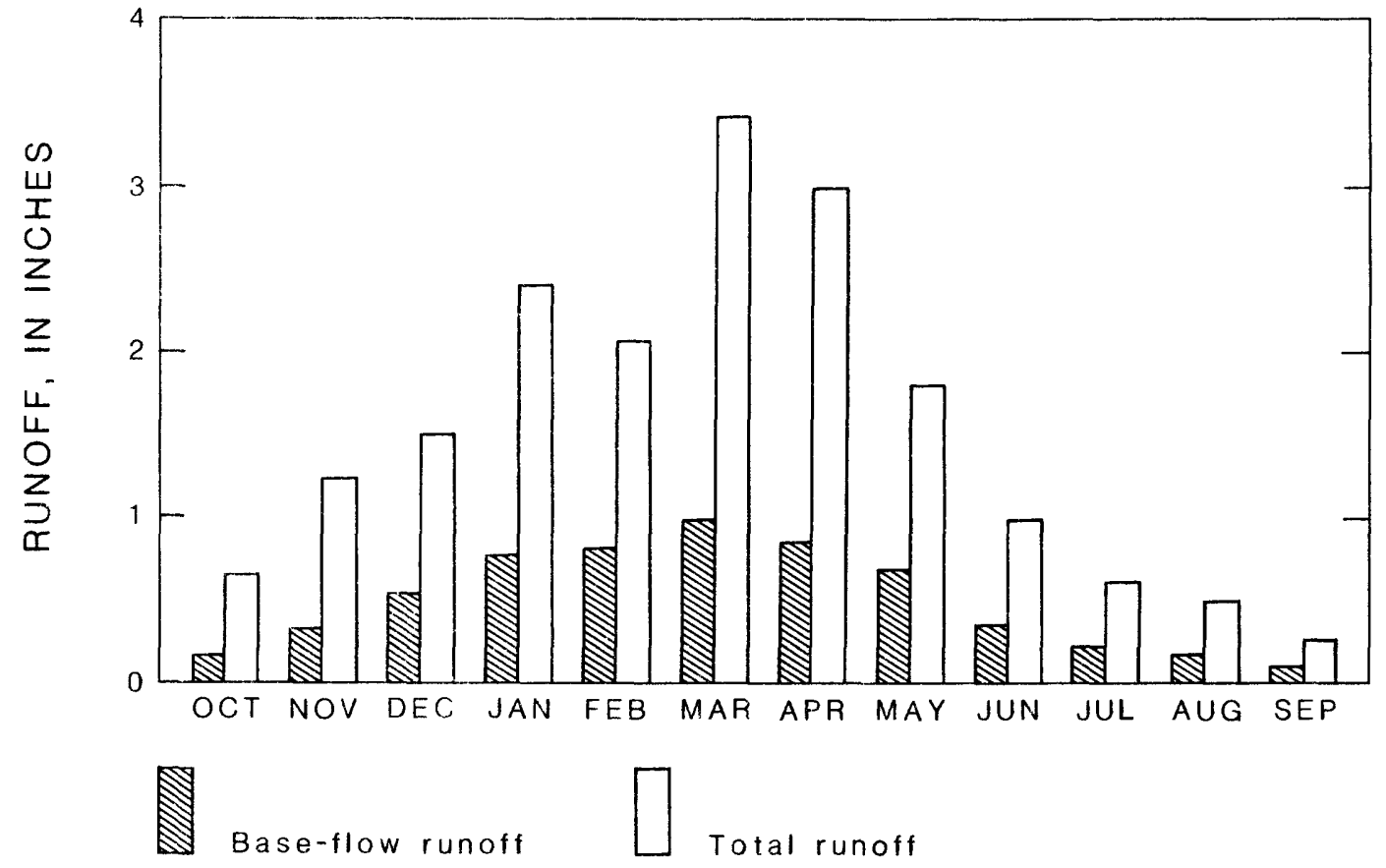

Figure 3.1-2 -- Average monthly base flow and total runoff from the Russell Fork basin, $1971-80$ and 1982 . 


\title{
3.2 Streamflow
}

3.2.1 Correlation between gaged and ungaged sites

\section{Statistics From a Gaged Station Are Used To Develop Streamflow Statistics For Ungaged Basins}

\begin{abstract}
Graphs that correlate streamflow data from ungaged streamflow sites with data from concurrent continuous-record gaging stations provide a method for obtaining flow statistics. Six streamflow measurements were used to develop streamflow statistics in ungaged basins.
\end{abstract}

Streamflow measurements were made at selected sites and correlated with concurrent flow at a continuousrecord gaging station located within the same basin in order to estimate streamflow statistics for subbasins not having continuous-record gaging stations. Figure 3.2.1-1 shows this type of correlation for Hurricane Creek above left Fork and Russell Fork at Haysi. Six measurements (August 1981 to October 1982) at each site are correlated with flows at the Hays 1 gage.

The $Q_{50}$ streamflow for Russel1
Fork at Haysi is 135 cubic feet per second $\left(\mathrm{ft}^{3} / \mathrm{s}\right)$. This statistic means that 50 percent of the time, the Russe11 Fork streamflow is greater than or equal to $135 \mathrm{ft}^{3} / \mathrm{s}$. Horizontally across from where the Russell Fork $Q_{50}$ line intersects the correlation line is the $Q_{50}$ value for the ungaged site. The estimated $Q_{50}$ streamflow for Hurricane Creek is about $0.67 \mathrm{ft}^{3} / \mathrm{s}$. This correlation gives estimated flow statistics for a stream, as shown on the figure. Caution must be used when obtaining flow statistics beyond the range of measurements for an ungaged basin. 


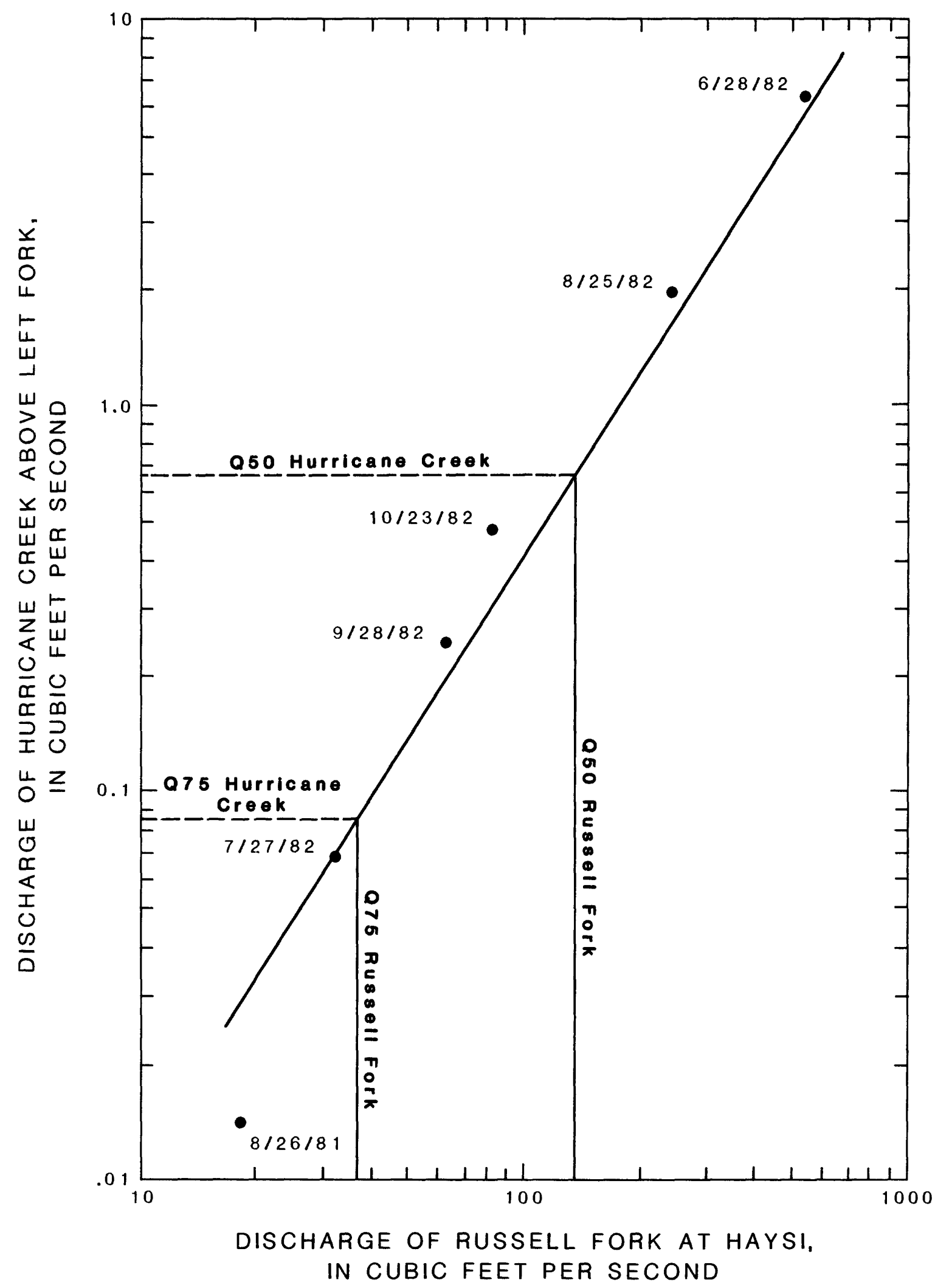

Figure 3.2.1-1 -- Streamflow correlation of Russell Fork at Haysi, Va. and Hurricane Creek. 


\subsection{SURFACE-WATER HYDROLOGY (continued)}

\subsection{Streamflow}

\subsubsection{Flow duration}

\section{Estimated Flow-Duration Statistics For Ungaged}

Sites ObTained By Streamflow CoRrelation

Flow-duration statistics were estimated for 28 small ungaged sites using flow data from the Russell Fork gaging station at Haysi.

A flow-duration curve is a cumulative-frequency curve that indicates the percentage of time specified discharges were equaled or exceeded during a given time period. The lowor base-flow segments of these curves are useful in assessing the effects of geology and man's activities on the hydrologic system.

Flow-duration statistics $\left(Q_{50}\right.$, $Q_{60}, Q_{75}$, and $Q_{90}$ ) are estimated for 28 ungaged streamflow sites draining the upper Russe11 Fork basin utilizing data from the gage on Russell
Fork at Haysi. Table 3.2.2-1 1ists flow statistics, basin area, and percent of area disturbed by surface mining. The table is sorted into increasing mining and basin size. In the table, estimated flow statistics compare flow data for basins of differing areal extent. The $r^{2}$ value on the table is a correlation coefficient, which statistically shows the closeness of $\mathrm{flt}$ of the measurements with the correlation curve. The closer the $r^{2}$ value is to 1.0 , the closer the data points are to the curve. 


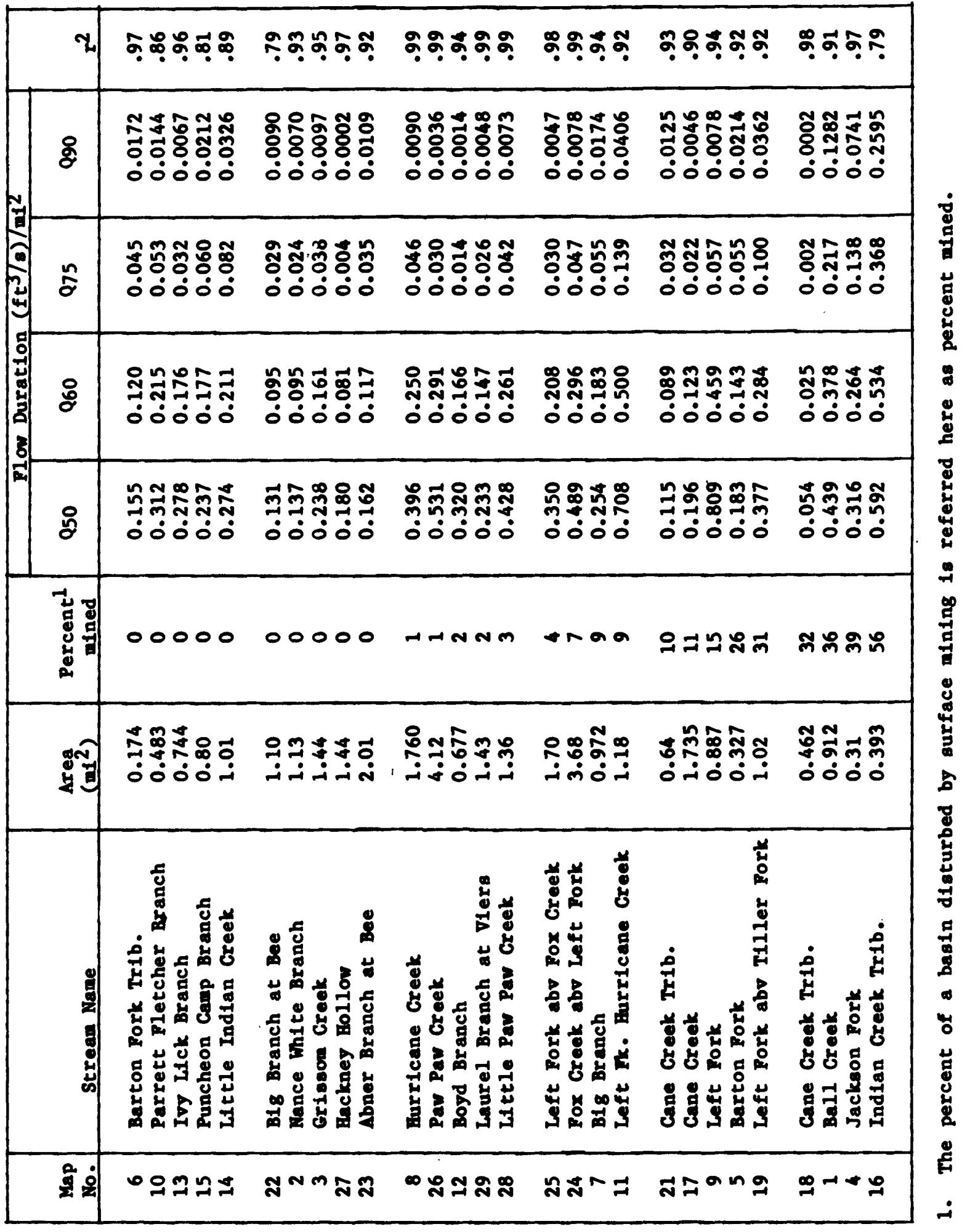




\subsection{Streamflow}

\subsubsection{Flow recession}

Base-Flow Recession Curves Show Ground-Water Discharge Ánd Seasonal Variation Due to EVAPOTRANSPiration

A base-flow recession curve from a streamflow hydrograph 18 a measure of the rate of decline in ground-water storage within a basin.

Flow recession is the rate of streamflow decrease; during base-flow periods, it approximates the decline in ground-water storage in a basin. Recession curves are developed by selecting straight-line segments of stream hydrographs that show flow after storm events and transposing these segments onto a stralght line through the range of discharges observed.

Figure 3.2.3-1 is a streamflow hydrograph for Barton Fork near
Councl1, Va., for the period October 1981 to September 1982. As shown in the figure, the recession lines are drawn when the hydrograph changes slope after a peak. The April and June-July recession lines 11lustrate the change in slope of recessions due to seasonal losses due to evapotranspiration. The June-July recession line is steeper, Indicating loss of water from evapotranspiration. The April recession line is flatter, indicating minimal effects from evapotranspiration. 
Barton Fork near Council, Va.

PERIOD OF RECORD: Oct. 1, 1981 to Sept. 30,1982

AREA : 1.23 square miles

SURFACE MINING DISTURBANCE : $29 \%$

AVERAGE DISTANCE FROM STREAM TO DIVIDE : 940 teet

DECAY RATE PER LOG CYCLE : 81 days

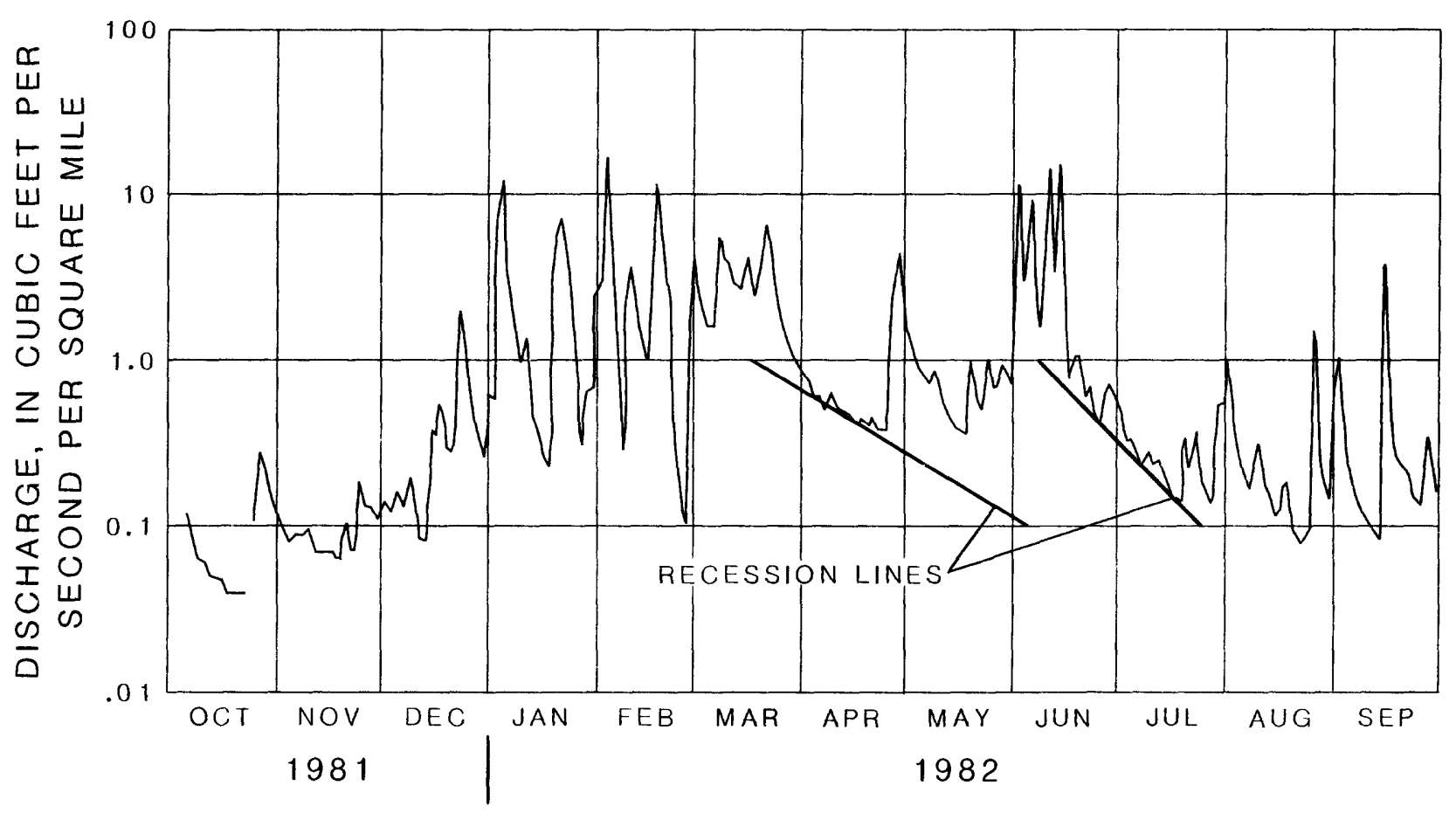

Figure 3.2.3-1 -- Streamflow hydrograph for Barton Fork near Council, Va., showing recessions. 
4.0 GROUND-WATER HYDROLOGY

puge 25 follows 23 


\title{
4.0 GROUND-WATER HYDROLOGY \\ 4.1 Observation Wells
}

\subsubsection{Description}

\section{Observation Wells Were Installed In A Valley Bottom And On A Ridgetop To Evaluate Different HydRologic EnVIRONMENTS}

\begin{abstract}
Eight observation wells were installed in the Grissom Creek subbasin to evaluate the various hydrogeologic environments present in the area. Three wells were installed in a valley bottom to monitor water levels and to conduct aquifer tests in alluvium, weathered rock, and unweathered rock. Five wells were drilled on a ridgetop to monitor water levels and to conduct aquifer tests on the weathered material and unweathered rock to the depth of the first coal bed, a sandstone-siltstone contact, and three coal-bed zones.
\end{abstract}

Eight observation wells were drilled in the Grissom Creek basin. Three wells are located in the valley bottom near the mouth of Grissom Creek and five wells are located on a ridgetop between Grissom Creek and Nance White Branch. The observation wells were constructed so that water levels and aquifer properties at specific-depth intervals below the ridgetop, and in the alluvium, weathered bedrock, and unweathered bedrock in the valley could be determined. Construction features and locations of the observation wells are shown in figure 4.1.1-1.

Two we11s $(14 \mathrm{E} 40,14 \mathrm{E} 41)$ were drilled and one we11 point (14E44) was installed near the gaging station at the mouth of Grissom Creek. Well 14 E40 was drilled and cased through the alluvium to a depth of 14 feet using an 8-inch diameter bit. Water inflow to the hole increased with depth in the alluvium. After 6-inch diameter casing was installed and grouted, drilling continued to a depth of 60 feet with a 6-inch bit. A gradual increase in water inflow was encountered to the Jawbone coal bed of the Norton Formation. A minor increase in water inflow occurred below the Jawbone coal bed. Well $14 \mathrm{E} 41$ was similarly drilled to a depth of 60 feet; after 6-inch casing was installed and grouted, drilling continued with a 6-inch diameter bit to a depth of 125 feet. Very little water was encountered below the cased section of the hole. Well 14E44 is a 2-Inch diameter well point driven into alluvium near the bank of Grissom Creek; the water level was 2 feet below land surface. An unused well (14E42) at the" site also was used as an observation well; the well is 60 feet deep and has 4-inch casing to a depth of 14 feet.

Five wells were drilled in a cluster on a ridgetop between Grissom Creek and Nance White Branch to monitor differences in water levels between major coal beds in the Norton Formation and to determine the hydraulic properties of the rocks. No measurable amount of water was produced during the drilling of any of the ridgetop wells. Two 8-inch diameter holes (14E25 and 14E26) were drilled to depths of 56 and $101 \mathrm{ft}$, respectively, and were cased with 4-inch diameter PVC pipe. In well 


\subsection{Observation Wells (continued)}

\subsubsection{Description (continued)}

14E25, casing was slotted from the bottom of the well (in the Upper Banner coal bed) to the bottom of the soll zone at a depth of two feet, a gravel pack was installed, and the casing was grouted in with a 2-foot cement cap to the surface. Well 14E26 had slotted PVC casing installed from 56 feet (below the Upper Banner coal bed) to the bottom, and a gravel pack was installed. The annular space between the casing and drilled hole was grouted with bentonite and cement from the top of the gravel pack to land surface. Well 14E26 does not reach the Lower Banner coal bed but is finished fust below a sandstone-siltstone contact. Three additional 8-inch diameter holes
(14E37, 14E38 and 14E39) were drilled to the bottom of coal beds. Six-inch casing was installed to the bottom of each. Cement grout was injected into the well and forced up the outside annulus to the surface. Drilling was continued into the next coal bed. The lower section of each well is an open hole. Well 14E39 is open from the bottom of the Lower Banner coal bed into the Kennedy coal bed at a depth of $243 \mathrm{ft}$. We11 14E38 is open from the bottom of the Rennedy coal bed into the Ally coal bed at $423 \mathrm{ft}$. and We11 14E37 is open from the bottom of the Ally coal bed through the Raven 1, 2, and 3 coal beds, to a depth of $582 \mathrm{ft}$. 

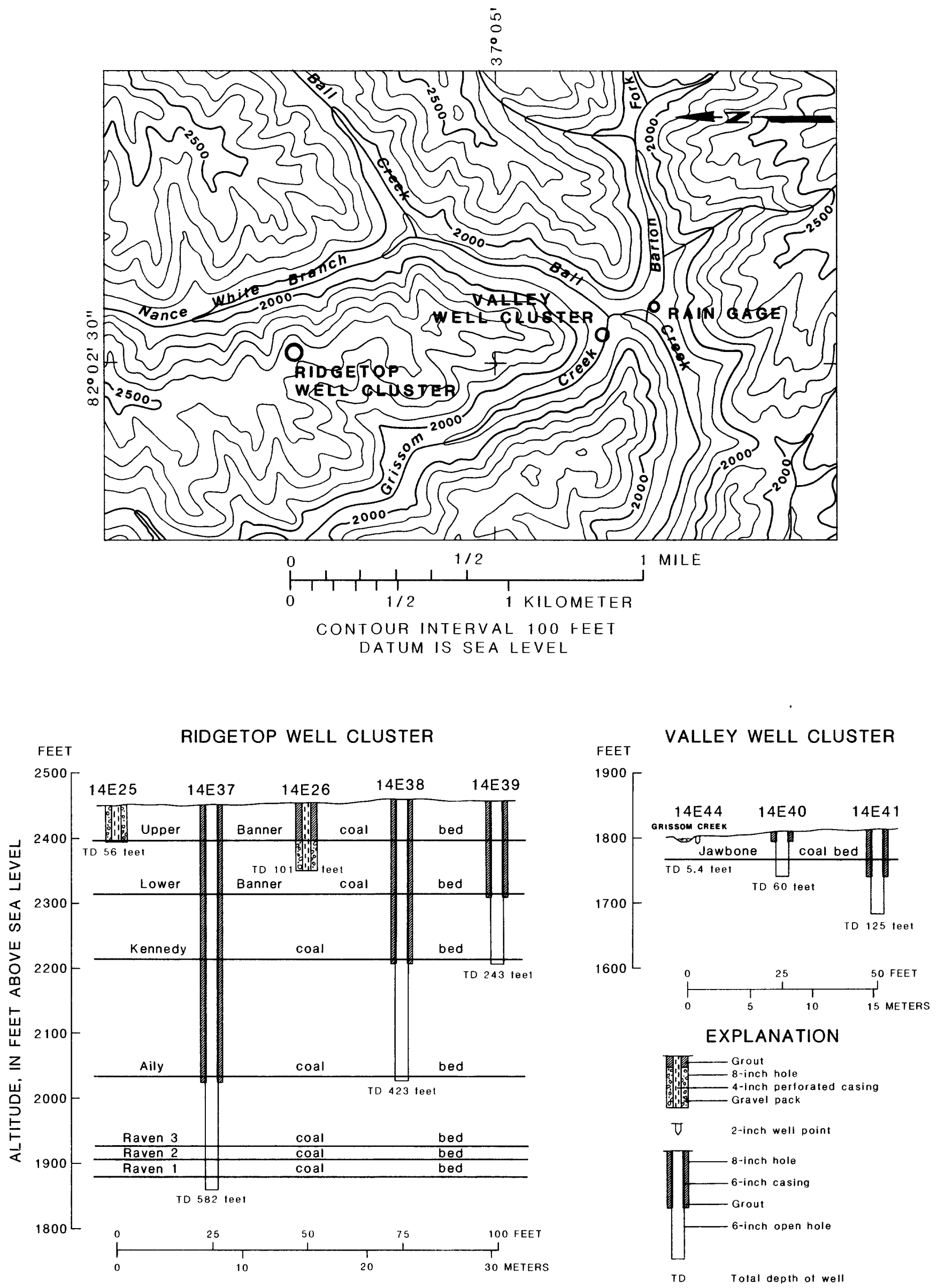

Figure 4.1.1-1-- Construction features and location of observation wells. 


\title{
4.1 Observation Wells
}

\subsubsection{Water-Zevel fluctuations}

Water-Level Fluctuations In Valley Observation Wells Reflect Changes In Climatic Conditions; Ridgetop ObSERVATion Wells Tap Perched Water Zones at Coal Beds

\begin{abstract}
Water-level recorders were installed on three valley observation wells and five ridgetop wells in October-November 1981. Raingages were installed at Barton Fork, about 1,000 feet from the valley we1ls, and at Birchleaf, about 15 miles away. Water-level hydrographs and precipitation records for valley and ridgetop wells show some correlation of waterlevel response to rainfall and dry periods. The ridgetop observation wells tap a series of perched-water zones assoclated with coal beds.
\end{abstract}

Continuous water-level recorders were installed in three valley observation we11s (14E40,14E41, and 14E44) at the mouth of Grissom Creek in November 1981. Precipitation was measured at a raingage at the mouth of Barton Fork, approximately 1,000 feet from the wells. Precipitation also was measured at Birchleaf, Virginia, about 15 miles away. This record is used to supplement missing data records for May, June, and July 1982 at the Barton Fork raingage.

Hydrographs from the three valley wells and monthly precipitation totals for the period October 1981 through May 1983 are shown on figure 4.1.2-1. The top hydrograph is for a 5.4-foot long well point (14E44) installed in alluvium near the edge of Grissom Creek. The middle hydrograph is for a well (14E40) finished in the weathered zone (hole open from 14 to 60 feet). The bottom hydrograph is for a well (14E41) finished in unweathered sandstone and siltstone (hole open from 60 to 125 feet).

In general, water-1evel fluctuations correlate with variations in precipitation and evapotranspiration.
The monthly magnitude of water-level fluctuation is greatest in the 60foot deep well (14E40). Seasonal variations in water levels are evident in all three of the hydrographs.

Water-level recorders were installed on five ridgetop observation wells in October-November 1981 and operated through May of 1983. The figure shows the water-level hydrographs of the ridgetop wells. Those wells are location about $1 / 2$ mile from the valley wells and about $3 / 4$ mile from the raingage on Barton Fork. Water-level trends in the shallowest (14E25) and deepest (14E37) wells were similar. It appears that water-level fluctuations in $14 \mathrm{E} 25$ are directly related to rainfall and evapotranspiration--that is, water levels rise with increased precipitation but decline with increased evapotranspiration. The deep well is finished at an elevation below the adjacent stream valleys.

The peak water level on the hydrograph for well 14E37 is the result of a slug test where 20 gallons of water were injected into the well. Recovery to the projected static water level required more than 40 
4.0 GROUND-WATER HYDROLOGY (continued)

\subsection{Observation Wells (continued) \\ 4.1.2 Water-level fluctuations (continued)}

days, which indicates a very low transmissivity. The peaks on the hydrographs for we11s 14E25, 14E26, and 14E39 recovered from similar slug injections in 1 to 5 days.

Each ridgetop well is open to a different coal bed or contact, and water levels in each well stand at different altitudes. Unsaturated zones were encountered between coal beds, indicating the presence of a series of perched water zones above the coal beds. 

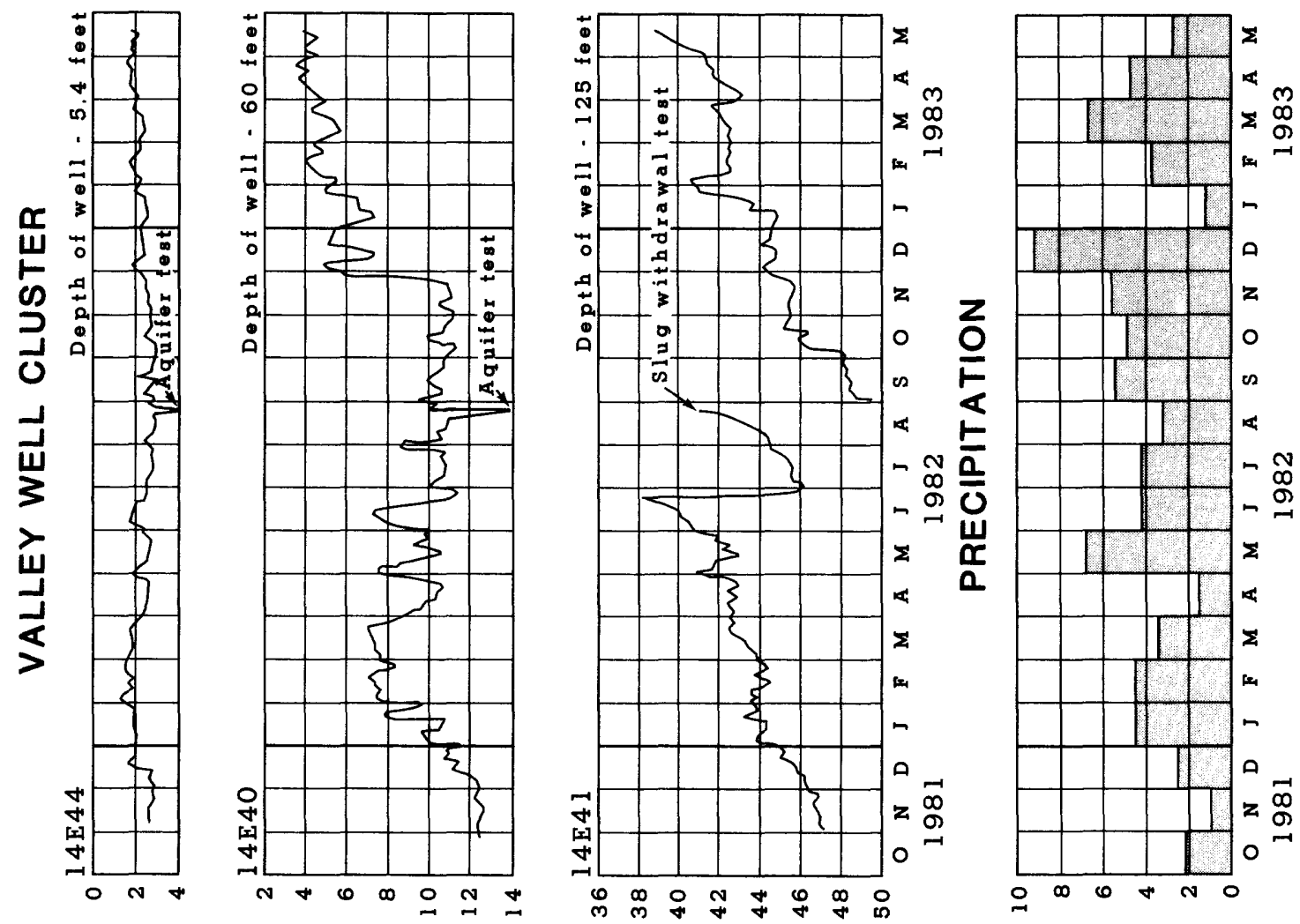

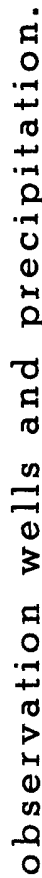
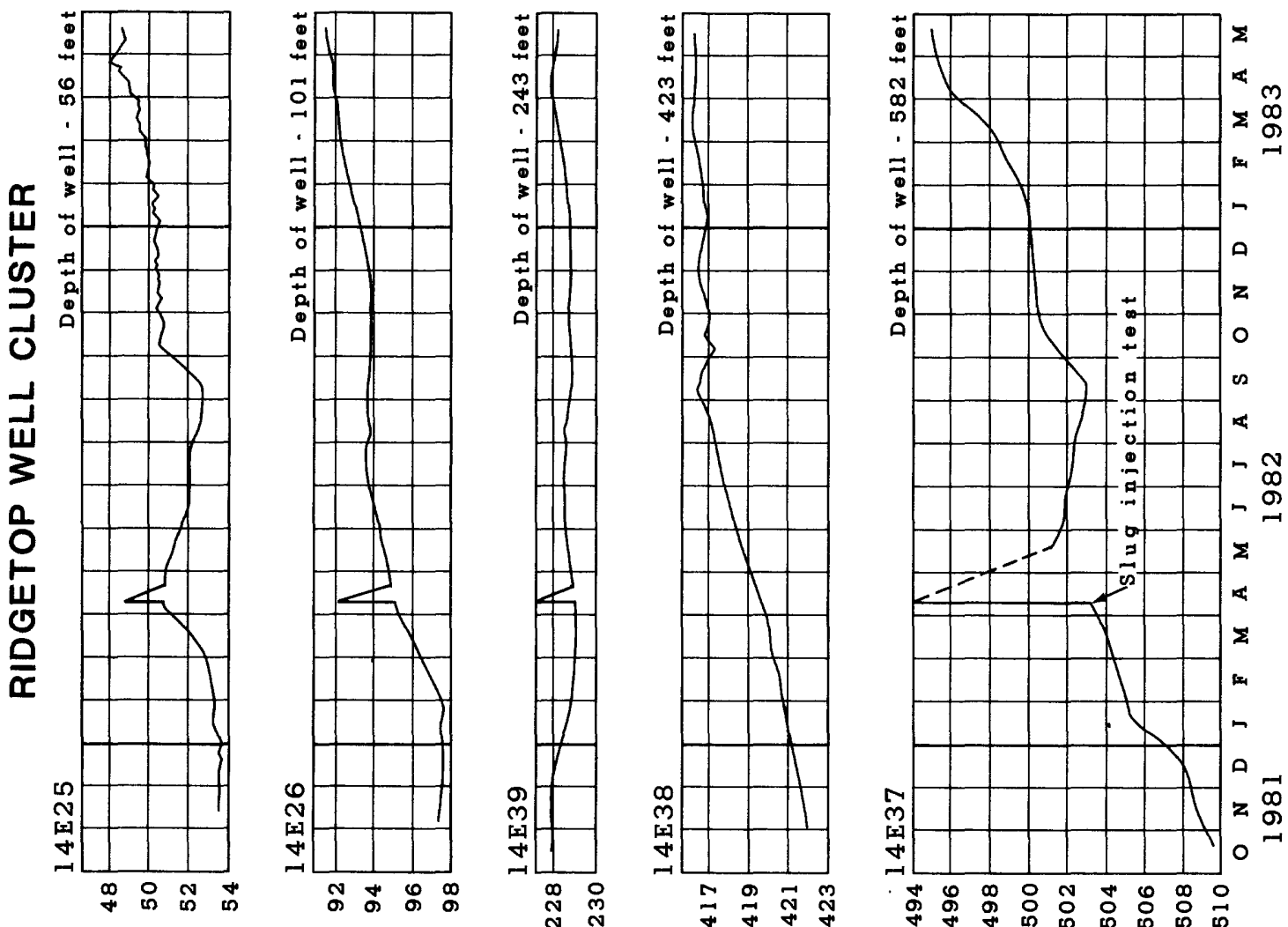

D

稰 


\title{
4.0 GROUND-WATER HYDROLOGY (continued)
}

\section{- 4.2 Aquifer Hydraulic Properties}

4.2.1 Aquifer tests of valley wells

\section{Aquifer Tests In Valley Indicate A Wide Range OF Transmiss IVITIES}

\begin{abstract}
Aquifer tests of the valley observation wells at the mouth of Grissom Creek were conducted during the week of August 23-27, 1982. Estimated transmissivities ranged from $270 \mathrm{ft}^{2} / \mathrm{d}$ in the alluvial material, 120 to $140 \mathrm{ft}^{2} / \mathrm{d}$ in the weatheredbedrock zone, and about $0.15 \mathrm{ft}^{2} / \mathrm{d}$ in the unweathered bedrock. Storage coefficients from $4.0 \times 10^{-4}$ to $4.8 \times 10^{-4}$ were determined for the weathered-bedrock zone.
\end{abstract}

The movement of water within an aquifer depends, in part, on the hydraulic properties of the aquifer. Two principal hydraulic properties of an aquifer are storage coefficient and transmissivity.

Two techniques for determining aquifer hydraulic properties were used. The most common and wideiy used technique for determining aquifer properties is an aquifer test. It involves pumping a well. for a period of time and measuring the changes in water levels in both the pumped well and adjacent observation wells. The other technique rapidly injects or withdraws a measured volume of water; this is followed hy measurements of the water-1evel response to this change in volume over time. This latter procedire is known as a slug test.

Aquifer tests were conducted at wells in the bottom of the valley (14E40, 14E41, and 14E44) August 2327,1982 . Pumping rates, length of tests, total drawdowns, and other pertinent information on the wells tested are provided in table 4.2.1-1. Two methods of analysis are used. One method (Cooper-Jacob, 1946, p. 529), consists of plotting waterleve1 drawdown as a function of time on semilogarithmic graph paper (time is plotted on the logarithmic scale, as shown in fig. 4.2.1-1). This method was applied to a pumped well (14E40) and to an observation well (14E42) 35 feet away. Transmissivity values obtained were about $130 \mathrm{ft}^{2} / \mathrm{d}$ for the observation we11 and the pumped well. Both wells are finished in weathered bedrock and the Jawbone coal bed. A pumping test of the shallow 5.4 foot well point (14E44) was conducted, and the transmissivity w.1s estimated to be about $270 \mathrm{ft}^{2} / \mathrm{d}$ for the alluvial material.

Arotier method of aquifer data andysis is the type curve matching teichnique. This method involves plotting time $(t)$ and drawdown (s) on $\log 1 \mathrm{l} \cdot \mathrm{g}$ paper (fig. 4.2.1-2) and mitchine this plot with type curves. "rlysis of the shape of the curves or the mulfer test in the weathered redrock in we $1114 \mathrm{E} 40$ and $14 \mathrm{E} 42$, indicates a delayed yield from aquifer storage (Boulton, 1963, flg. 1). The curve for well 14E42 also fits the dimensionless type curves for nondimension response to pumping a fully penetrating well in an unconfined aquifer (Stallman, 1965, figures 10 and 12). Transmissivities of about $120 \mathrm{ft}^{2} / \mathrm{d}$ for we11 $14 \mathrm{E} 42$ and about $140 \mathrm{ft}^{2} / \mathrm{d}$ for we11 $14 \mathrm{E} 40$ using the 


\subsection{GROUND-WATER HYDROLOGY (continued)}

\subsection{Aquifer Hydraulic Properties (continued)}

\subsubsection{Aquifer tests of valley wells (continued)}

Boulton equation, and about $120 \mathrm{ft}^{2} / \mathrm{d}$ for $14 \mathrm{E} 42$ using the Stallman equation were determined. Storage values for $14 \mathrm{E} 42$ were $4.0 \times 10^{-4}$ by the Boulton method (where $S=4 \mathrm{Tt} / \mathrm{r}^{2}$ ) and $4.8 \mathrm{x}$ $10^{-4}$ by the Stallman equation (where $\left.S=T t / r^{2}\right)$. $T$ is transmissivity in $\mathrm{ft}^{2} / \mathrm{d}$ from the above equation, $t$ is the time at the match point, and $r$ is the radius from the pumping well to the observation we11.

We11 14E41, which is finished in unweathered bedrock, was pumped for 9 minutes at $10 \mathrm{gal} / \mathrm{min}$ at which time the water level declined 95 feet. Analysis of the water-level recovery data using a slug test analysis method (Cooper and others, 1967, p. 267) provides an estimated transmissivity of $0.15 \mathrm{ft}^{2} / \mathrm{d}$.

Analysis of aquifer- and slugtest data shows a rapid decline in the transmissive properties of the bedrock with depth. Drill cuttings from the wells indicate the presence of a zone of weathered bedrock that is conductve to the transmission and storage of ground water. The weathered zone is more highly fractured in addition to having openings created by the weathering process. The additional openings and volds allow for greater storage and movement of ground water.

Table 4.2.1-1. Aquifer test data for valley material.

\begin{tabular}{l|c|c|c|c}
\hline We11 no. & $\begin{array}{c}\text { Pumping rate } \\
\text { (ga1/min) }\end{array}$ & $\begin{array}{c}\text { Length of test } \\
\text { (minutes) }\end{array}$ & $\begin{array}{c}\text { Total drawdown } \\
\text { (feet) }\end{array}$ & Remarks \\
\hline $14 \mathrm{E} 40$ & 11.5 & 320 & 6.89 & 54.0 \\
$14 \mathrm{E} 41$ & 10.0 & 9 & 6.79 & $\begin{array}{c}\text { Slug-test } \\
\text { analysis } \\
\text { Observat1on we11 } \\
\text { for we11 14E40 }\end{array}$ \\
$14 \mathrm{E} 42$ & 11.5 & 320 & 3.5 & \\
\hline
\end{tabular}




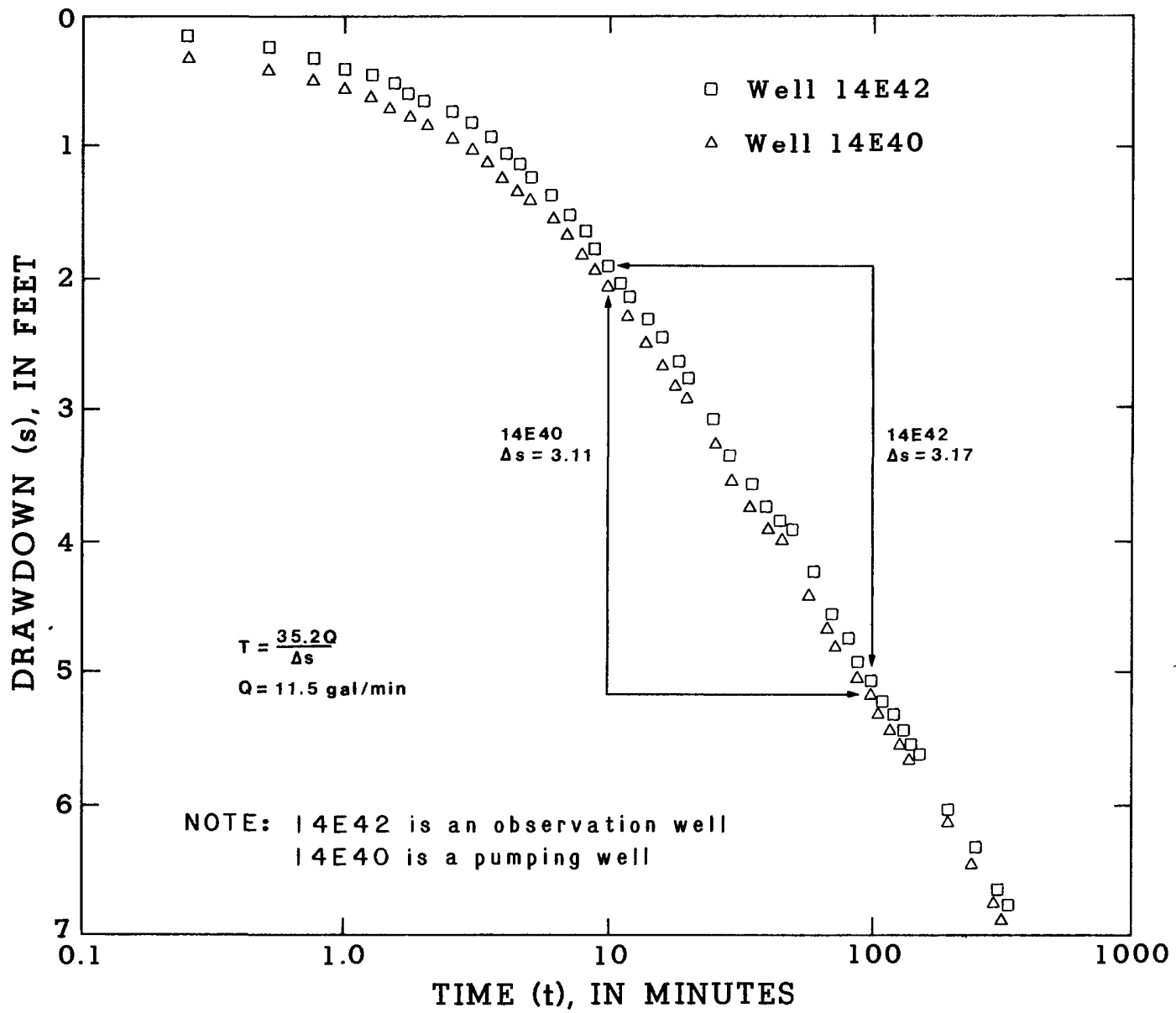

Figure 4.2.1-1-- Aquifer-test analysis for valley wells by straight-line method.

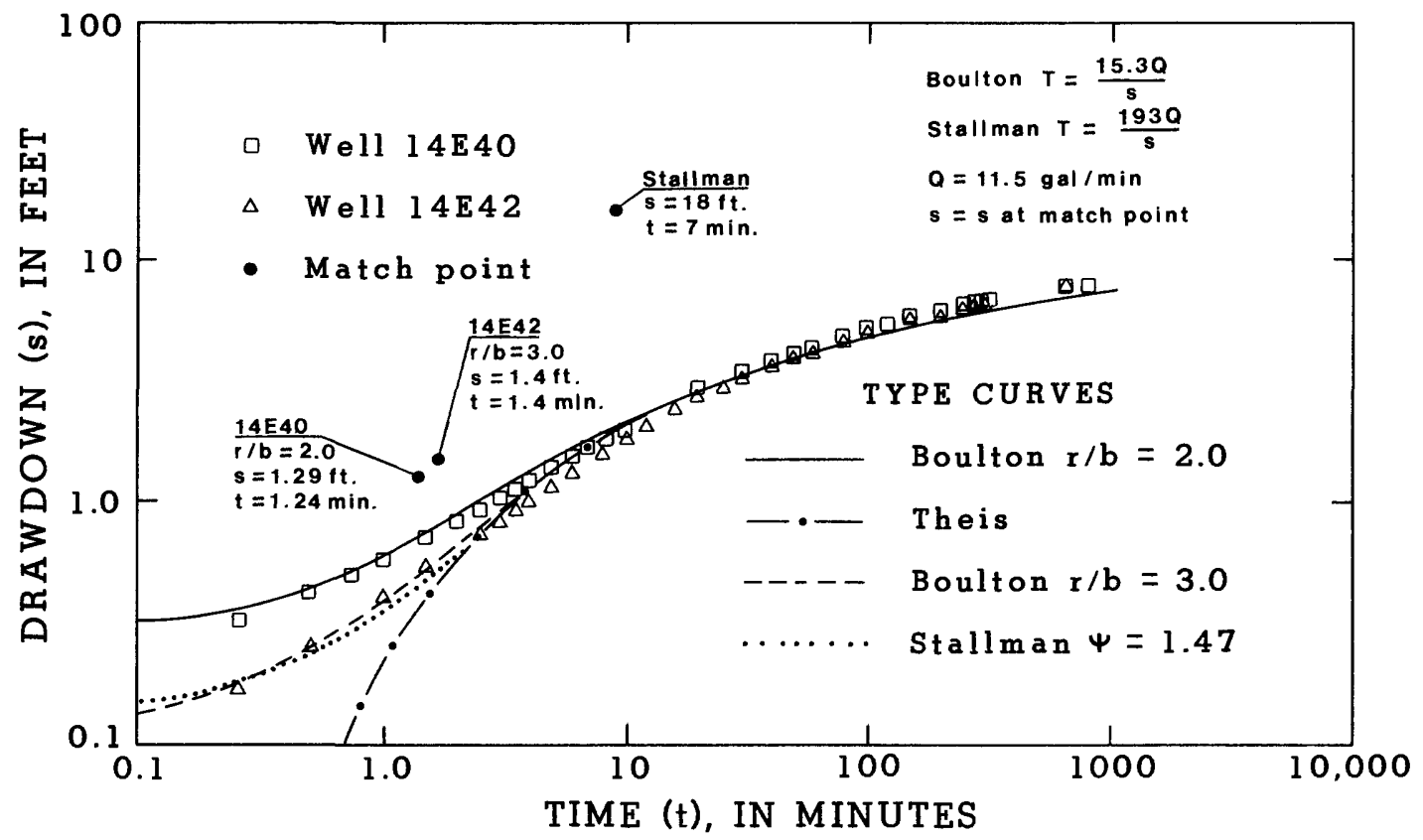

Figure 4.2.1-2 - Aquifer-test analysis for valley wells by type-curve method. 


\title{
4.0 GROUND-WATER HYDROLOGY (continued)
}

\subsection{Aquifer Hydraulic Properties \\ 4.2.2 Aquifer tests of ridgetop wells}

\section{Aquifer Tests Of Ridgetop Nells Indicate}

\section{A DeCrease In Transmissivity With Depth}

\begin{abstract}
Instantaneous injections (slugs) of water were used to evaluate the aquifer properties of three ridgetop we11s, (14E26, 14E39, and $14 \mathrm{E} 37$ ). Analysis of water-leve1 responses, after injection, yleld estimated transmissivity values of $0.29 \mathrm{ft}^{2} / \mathrm{d}$ at well 14E26 (101 feet deep), $0.088 \mathrm{ft}^{2} / \mathrm{d}$ at we11 $14 \mathrm{E} 39$ (243 feet deep), and $0.008 \mathrm{ft}^{2} / \mathrm{d}$ at we11 $14 \mathrm{E} 37$ (582 feet deep). Estimated storage coefficients are $1.0 \times 10^{-2}$ for wel1 $14 \mathrm{E} 26,1.0 \times 10^{-5}$ for we11 $14 \mathrm{E} 39$, and $1.0 \times 10^{-4}$ for we11 $14 \mathrm{E} 37$.
\end{abstract}

The volume of water in each well and absence of water encountered during drilling necessitated the use of slug tests to obtain transmissivity ( $T$ ) and storage coefficient (S) for the ridgetop observation-well cluster. Slug-test data were analyzed using a curve-matching method presented by Cooper and others (1967, p. 267). This method involves plotting $\mathrm{H} / \mathrm{H}_{0}$ as a function of time on semilogarithmic graph paper where $H$ is the head of water at time $t$ after injection and $\mathrm{H}_{0}$ is initial head at the time of injection (figure 4.2.2-1). Plots of these values are matched to a type curve of $\mathrm{H} / \mathrm{H}_{0}$ as a function of $\mathrm{Tt} / \mathrm{rc}^{2}$ at the point where $\mathrm{Tt} / \mathrm{r}_{\mathrm{c}}{ }^{2}=1.0$ ( $\mathrm{T}$ is transmissivity $(\mathrm{ft} / \mathrm{d}), t$ is time in days and $r_{c}$ is the radius of the we 11 , in feet). The time $(t)$. where $T t / r_{c}{ }^{2}=1.0$ is used to calculate transmissivity $\left(\mathrm{ft}^{2} / \mathrm{d}\right)$. Each type curve used in the analysis has a relative storage coef- ficient ( $S$ ) for the aquifer as determined by the equation that defines the curve. According to Cooper and others (1967), this coefficient has questionable reliability because the curves differ only slightly with an order-of-magnitude change in storage. The result is presented here as a relative storage value.

We11s 14E26, 14E39, and 14E37 were infected with 3,5 , and 20 gallons of water, respectively, on Apri1 8, 1982. As shown on the figure, we11 $14 \mathrm{E} 26$ has an estimated $\mathrm{T}$ of $0.29 \mathrm{ft}^{2} / \mathrm{d}$ and an $\mathrm{S}$ of 0.01 , wel1 $14 \mathrm{E} 39$ has an estimated $\mathrm{T}$ of 0.088 $\mathrm{ft}^{2} / \mathrm{d}$ and an $\mathrm{S}$ of 0.00001 , and wel1 $14 \mathrm{E} 37$ has an estimated $T$ of 0.008 $\mathrm{ft}^{2} / \mathrm{d}$ and an $\mathrm{s}$ of 0.0001 . Water encountered during drilling of the observation wells was restricted to coal beds and a thin (generally less than 1-foot thick) shale zone above the coal beds. 


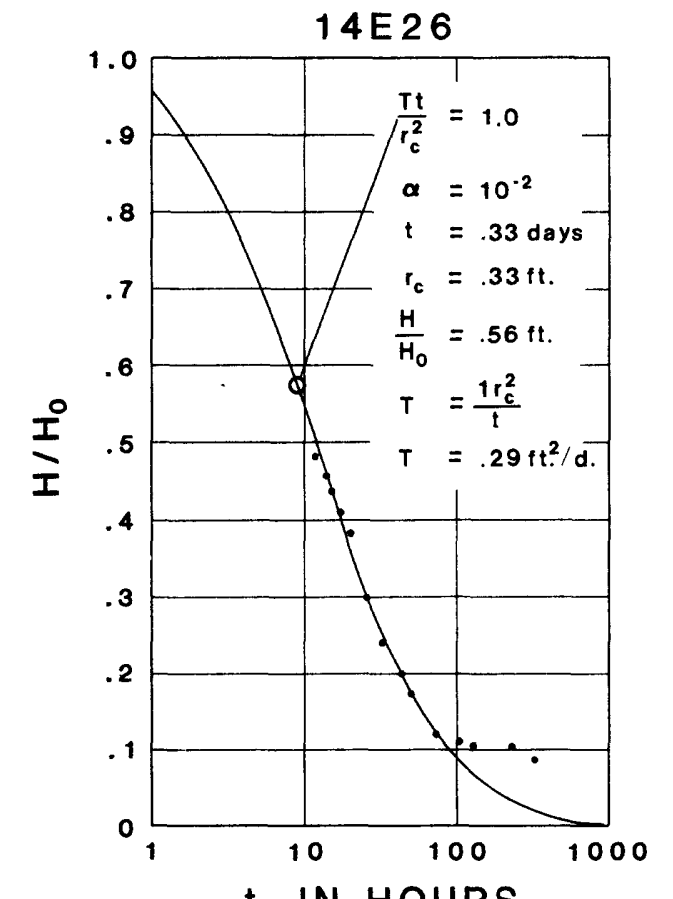

t, IN HOURS

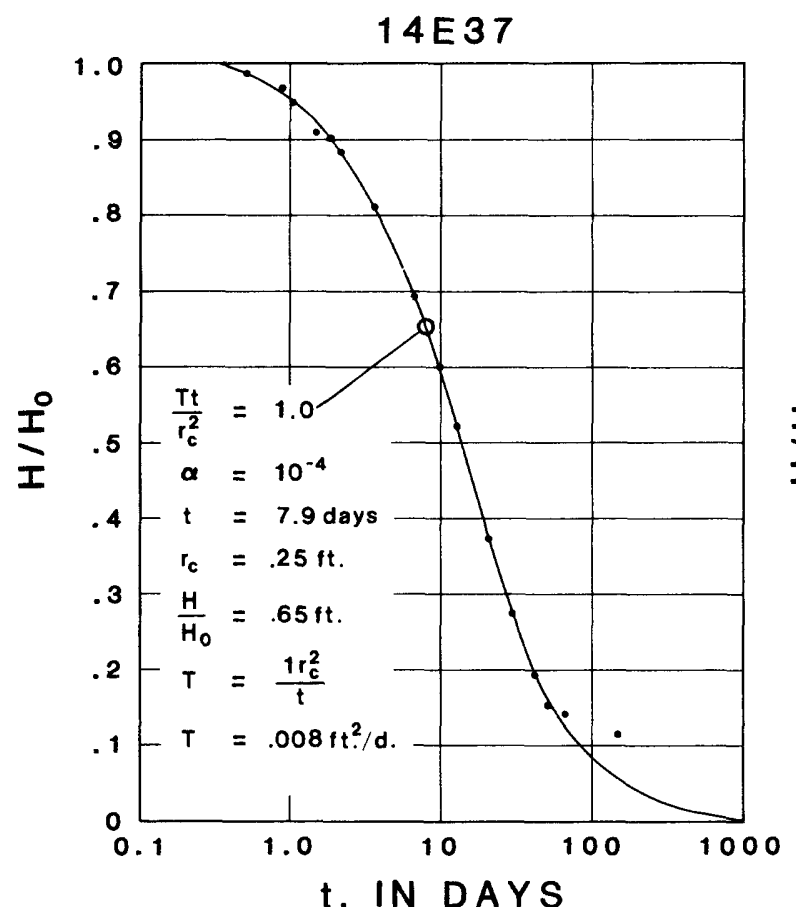

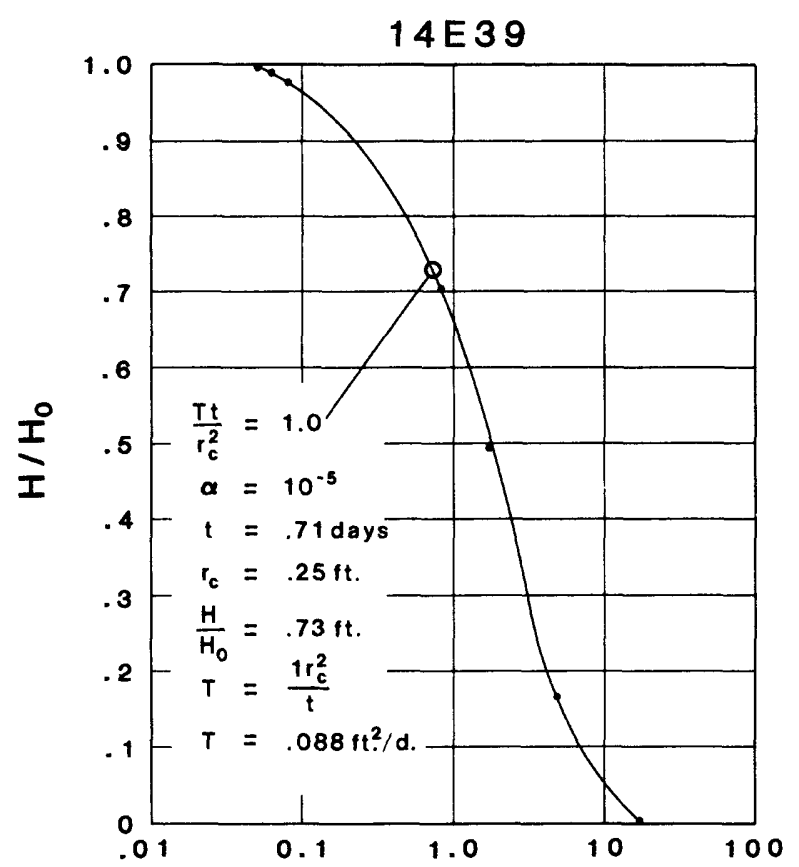

$t$, IN DAYS

TYPE CURVES

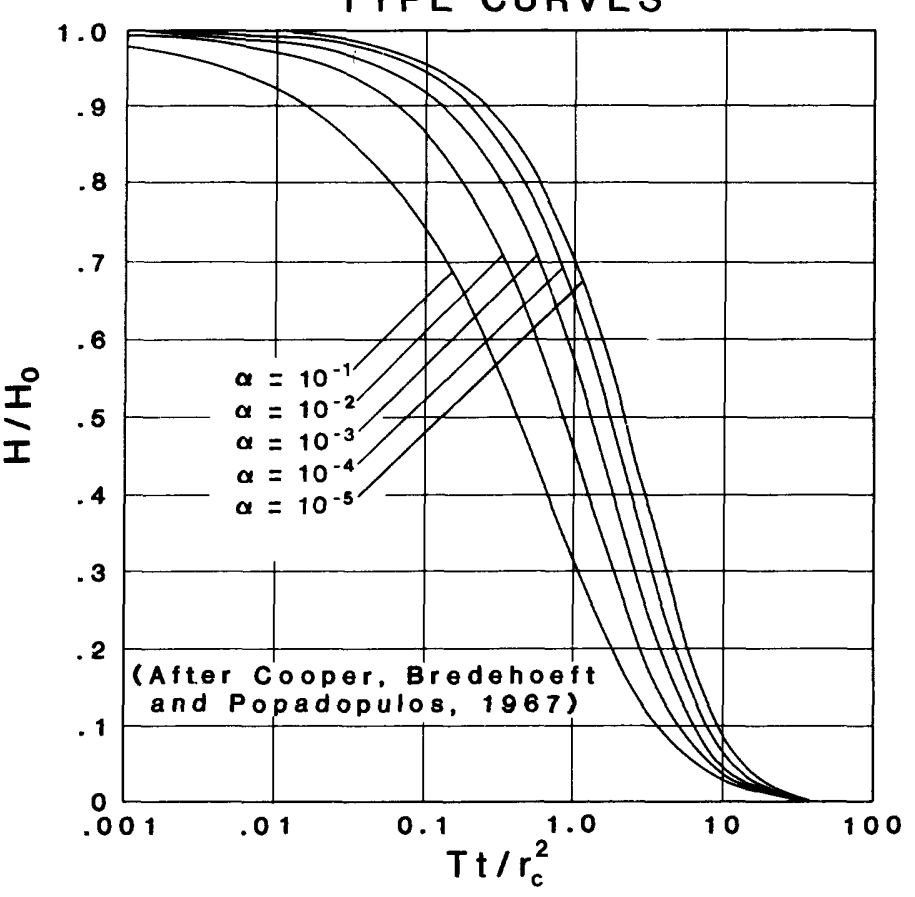

Figure 4.2.2-1 -- Slug-test results from ridgetop wells and type curves used in the analysis. 


\title{
4.0 GROUND-WATER HYDROLOGY (continued)
}

\subsection{Aquifer Hydraulic Properties}

4.2.3 Aquifer properties from streamflow

\section{ANALYS IS OF StREAMFLOW DATA \\ Yields Generalized Aquifer Properties Of A Basin}

\begin{abstract}
Streamflow recessions may be used to obtain average aquifer properties for a basin. Diffusivity (transmissivity divided by storage), can be determined from stream hydrographs. The technique of estimating diffusivity from stream hydrographs is shown.
\end{abstract}

Base flow is essentially ground water that discharges to a stream; thus, base-flow recession is a measure of declining ground-water storage in a basin. Rorbaugh (1964) derived an equation that estimates diffusivity for a basin by means of base-flow recessions. The Rorbaugh equation is $\mathrm{T} / \mathrm{S}=.933 \mathrm{a}^{2} / \Delta \mathrm{t}$, where $\mathrm{T}$ is transmissivity, $S$ is the storage coefficient, a is the average distance in feet from a stream to the divide in a basin, and $\Delta t$ is the time required for discharge to decrease through one log cycle on the graph. The value of " $a$ " is determined from the equation $a=A / 2 L$, where $A$ is the basin area, in square feet; and $L$ is the total length of stream channels in the basin, in feet.

Aquifer diffusivity values esti-
mated from recession curves are
approximate values because of the
effects of the short recession periods observed in this study, eva- potranspiration, and nonhomogeneity within the aquifers. According to Rorbaugh (1964), the rate of recession approaches a straight line $0.2 \Delta$ tays after a storm. Observed recession stabilization times support this estimate.

Figure 4.2 $\cdot 3-1$ shows a hydrograph for Grissom Creek for the period October 1, 1981 through September 30, 1982. A period during late March and early April 1982 shows a good recession and is used to illustrate the method of obtaining diffusivity from streamflow. A straight line is drawn along the slope of the hydrograph line as shown in the figure. In this case, the number of days for the line to decline from $1.0 .\left(\mathrm{ft}^{3} / \mathrm{s}\right) / \mathrm{mi}^{2}$ to $0.1\left(\mathrm{ft}^{3} / \mathrm{s}\right) / \mathrm{mi}^{2}$ is determined to be 56 days. Diffusivity in this case is then determined from the equation to be $24,800 \mathrm{ft}^{2} / \mathrm{d}$, using 56 days for $\Delta t$ and 1,220 feet for " $a$ ". 
Grissom Creek near Council, Va.

PERIOD OF RECORD: OCI. 1, 1981 to Sept. 30, 1982

AREA : 2.83 square miles

SURFACE MINING DISTURBANCE : $0 \%$

AVERAGE DISTANCE FROM STREAM TO DIVIDE : 1220 feet

DECAY RATE PER LOG CYCLE: 56 days

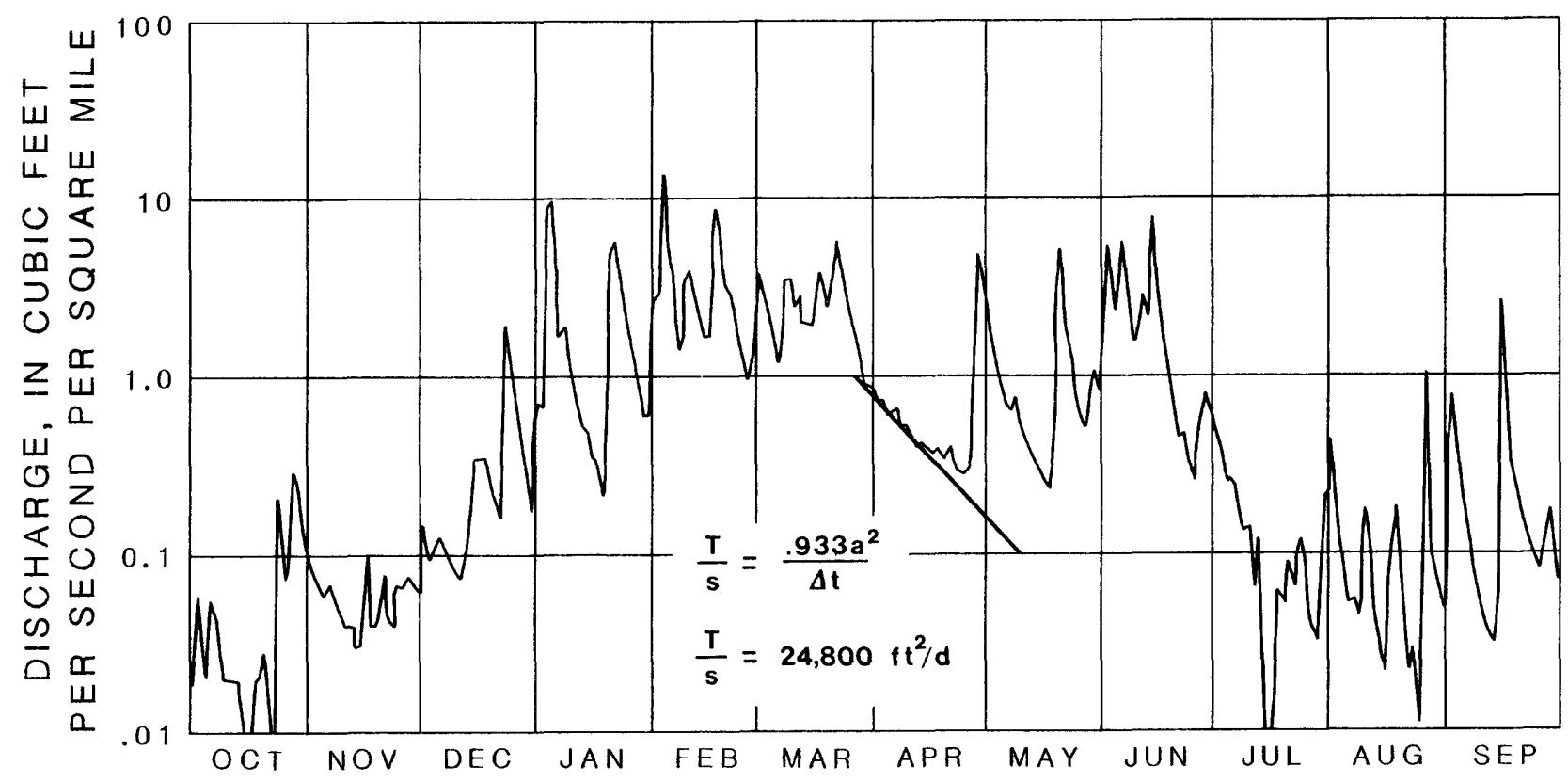

Figure 4.2.3-1 -. Streamflow hydrograph for Grissom Creek showing a recession period and diffusivity. 


\subsection{GROUND-WATER HYDROLOGY (continued) \\ 4.3 Conceptual Ground-Water Flow System \\ Results From Aquifer Tests Indicate Major Aquifers Are Alluvium And Weathered Bedrock}

A conceptualization of the ground-water system shows that ground-water flow occurs primarily within the colluviumalluvium cover on the hillslopes and valley floor, and within the coal beds and weathered bedrock. Results of aquifer tests indicate that these materials are the major aquifers in the study area. The tests indicate that transmissivity decreases with depth. The principal conponent of flow in the ridgetop and hillslope areas is primar11y downward. Seeps associated with coal beds are a result of lateral flow within the beds toward the edge of the hillslope. Most ground water flows laterally and upward toward the valley floor.

A conceptualization of the ground-water system in the study area is shown in figure 4.3-1. Groundwater flow primarily is within the colluvium-alluvium cover on the hillslopes and valley floor, and within the coal beds and weathered bedrock. Results of aquifer tests indicate that these units are the major aquifers. The same tests indicate the estimated transmissivity of colluvium-alluvium and weathered bedrock to be about 270 and $130 \mathrm{ft}^{2} / \mathrm{d}$ respectively, as compared to less than $1.0 \mathrm{ft}^{2} / \mathrm{d}$ for underlying unweathered bedrock. Flow in the ridgetop and h1llslope areas primarily is downward through weathered bedrock. Small amounts of ground water move downward through fractures and intersticial openings in the unweathered bedrock to coal beds.
Seeps are associated with coal beds that lie between shale and an underclay.

The higher transmissivity of coal beds results in some lateral ground-water flow within the coal beds toward the edges of hillslopes. Seeps along the edges of hillslopes and perched zones of ground water within the ridge result from this lateral flow. Water moving downward along hillslopes discharges locally to a stream in the valley floor. Ground-water flow is either to or from the stream, depending on the hydraulic gradient between the stream and aquifer material. Ground-water flow that does not discharge directly to the stream continues downgradient as underflow beneath the stream. 


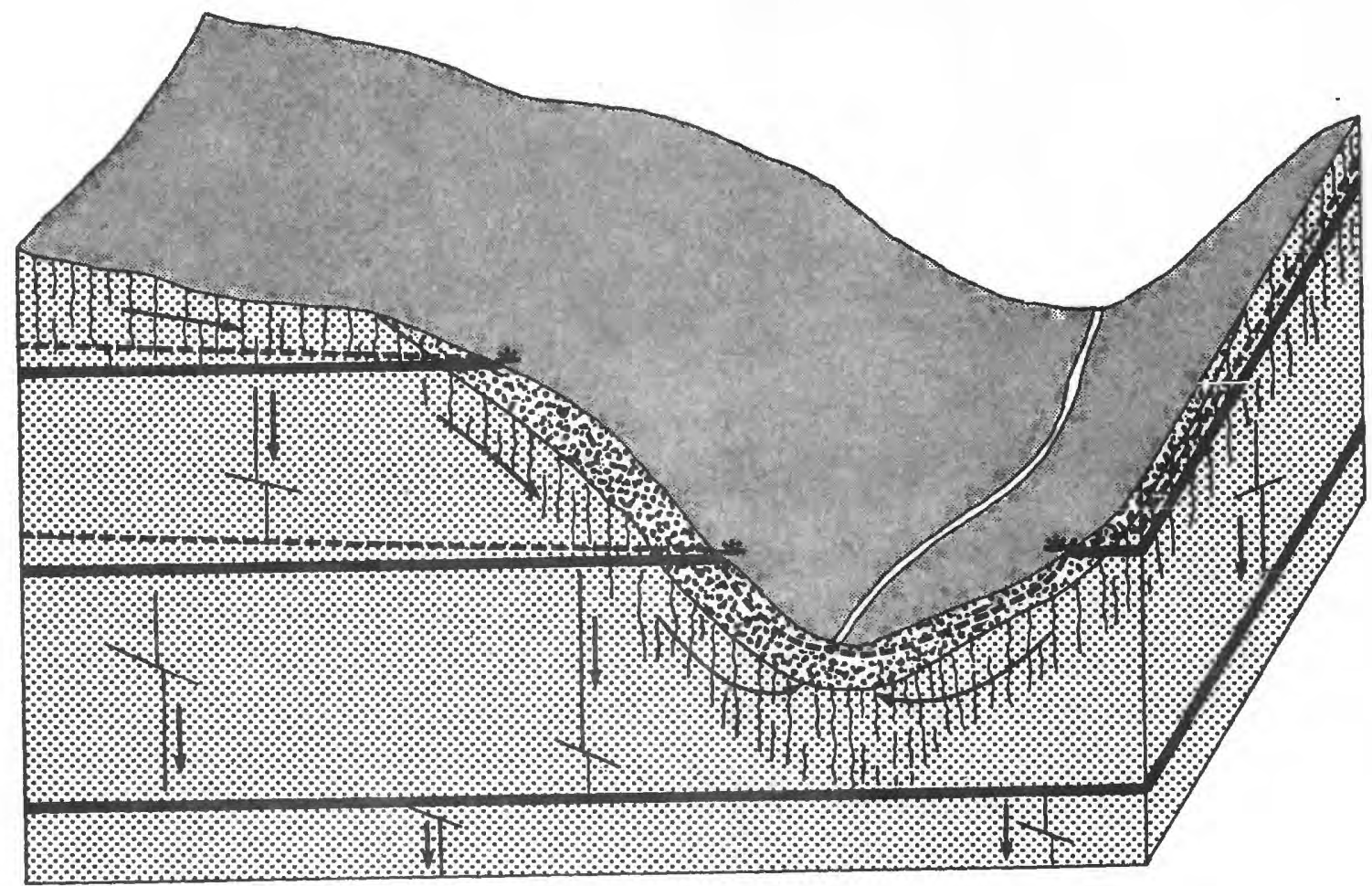

EXPLANATION

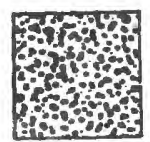

Colluvium and alluvium

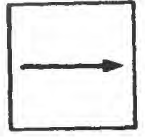

Ground-water

flow direction

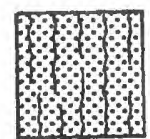

weathered bedrock

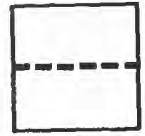

Water table

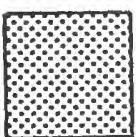

Unweathered bedrock

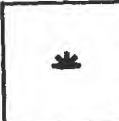

spring or seep

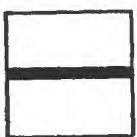

Coal bed

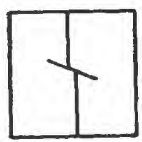

Fracture

Figure 4.3-1 - Conceptual ground-water flow system in the study area.

page 43 follows 
5.0 WATER QUALITY 


\title{
5.0 WATER QUALITY
}

\subsection{Ground-Water and Surface-Water Quality}

\author{
Water Quality During Low Flow Is Directly Related \\ Tó GROUND-WATER QUALITY
}

In the Barton Fork basin (m1ned), surface water is a calclumsulfate type at both high and low flows. In the Grissom Creek basin (unmined), water at high flow 18 also a calclumsulfate type, but, during low flow is a calclum-bicarbonate type very similar to the quality of ground water in observation wells.

Chemical analyses from the five ridgetop observation wells (see section 4.1) plot in the calciumbicarbonate field on a trilinear diagram (fig. 5.1-1). Data for well 14 E37 (the deepest we11, $582 \mathrm{ft}$ ) plot in the sodium-bicarbonate field. These data are consistent with data of Rogers and Powell (1983) that indicate that wells 50 to 150 feet deep throughout the area yield calcium-bicarbonate water.

Water-quality data for streams are also plotted on figure 5.1-1. Data for Grissom Creek samples, collected during high flows, plot in the calcium-sulfate field, whereas data collected during low flows plot in the calcium-bicarbonate field. Data representing water quality in Barton Fork at both high flow and low flow plot in the calcium-sulfate field. These data are consistent with the findings of Rogers and Powell (1983) who observed that stream water in unmined basins is a sulfate type at high flows and a bicarbonate type at low flows, whereas stream water from mined basins is a sulfate type at high and low flows.

A relationship between surface water, ground water, and mining in the study area can be seen in the trilinear diagram. Water-quality data representing low flows in the unmined Grissom Creek basin plot near water-quality data representing ground water from observation we11s; high flows in this basin plot in the calcium-sulfate fleld. These plots may result from flushing of the weathered-rock zone where sulfides are oxidized to sulfates by precipitation. The plot of the Barton Fork low-flow data in the calcium-sulfate field demonstrates the effect of surface mining on the quality of ground water and, therefore, stream-water quality. Water-quality data representing low flows plot closer to the bicarbonate field than do waterquality data representing high flows, demonstrating a trend similar to that seen in the Grissom Creek basin data. 


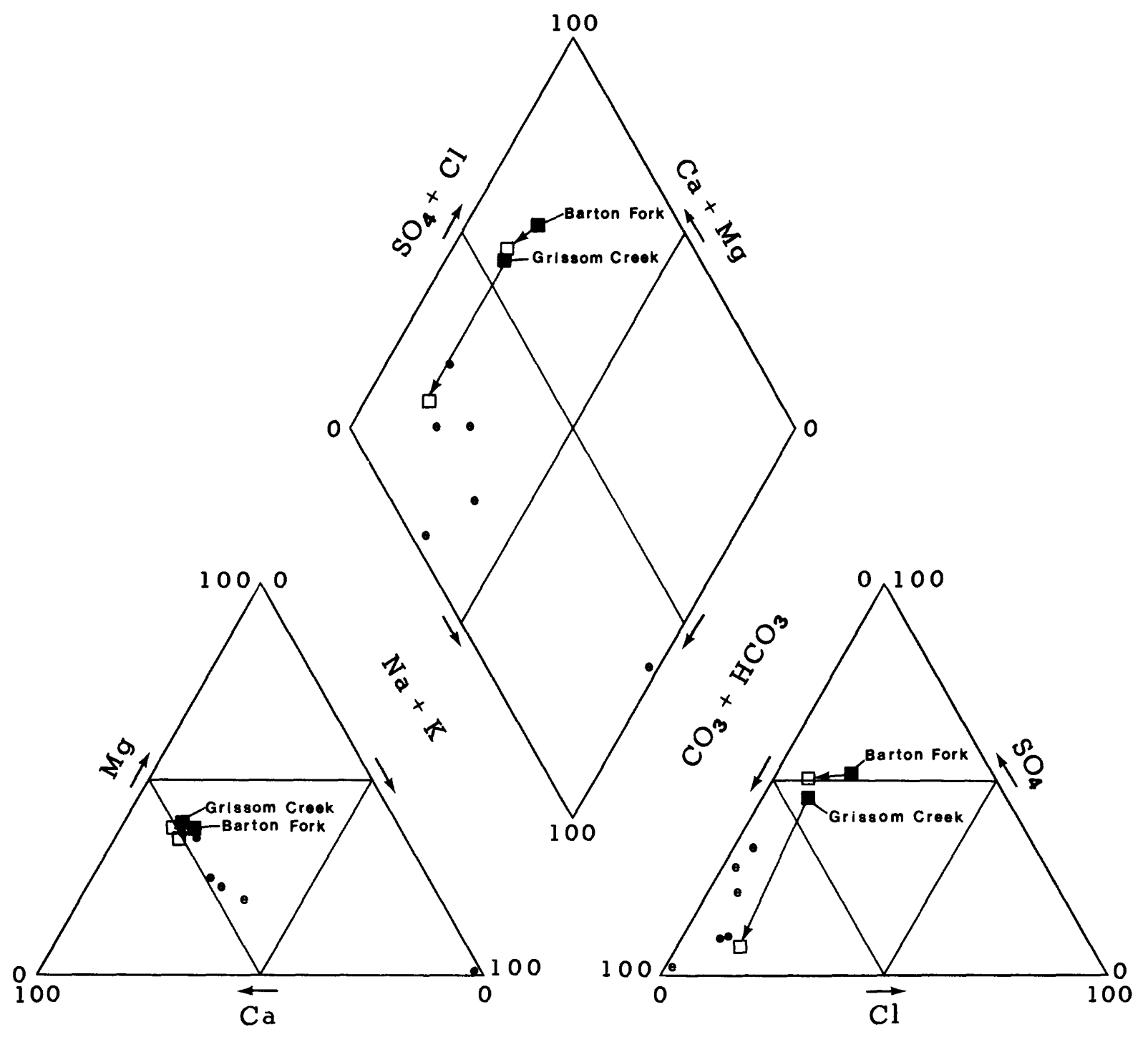

EXPLANATION

- Wells

- High flow

ㅁ Low flow

$\longrightarrow$ Trend in water quality

Figure 5.1-1 -. Ground-water and surface-water quality in the Grissom Creek and Barton Fork basins. 


\title{
5.2 Relation between Quality of Ground and Surface Water \\ Water Quality Of Grissom Creek Changes \\ With Changes In Source Of Ground Water
}

\begin{abstract}
In Grissom Creek, quality of stream water at very low flow indicates the primary source of strean-water 18 groundwater outflow from bedrock. At higher flows, water quality indicates the primary source of strean water 18 ground-water outflow from weathered overburden. At even higher flows, the water quality indicates the primary source of strean water is overland runoff.
\end{abstract}

Calcium and sodium in water from wells and springs in the Grissom Creek basin are plotted in figure 5.2-1. Data from wells finished in bedrock, dug wells finished in weathered overburden, and springs draining from fractures near the ridgetop, plot in separate groups showing that water from each source has a slightly different chemical character resulting from a different history of movement through weathered material and rock. Water-quality analyses from Grissom Creek at differing f1.'ws also are plotted on the figure and indicate a relation between discharge and sources of ground water.

Activities of calcium and sodium in a very low stream discharge $(0.02$ $\left.\mathrm{ft}^{3} / \mathrm{s}\right)$ plot similarly with those from drilled wells, indicating that the main source of water at very low flows is water that drains bedrock aquifers tapped by these wells. Calcium and sodium activities from somewhat higher flows (between about $0.1 \mathrm{ft}^{3} / \mathrm{s}$ and $\left.1.0 \mathrm{ft}^{3} / \mathrm{s}\right)$ generally plot similarly with those from dug we11s, Indicating that stream water at this discharge has as its primary source the weathered overburden tapped by these wells; these flows occur during storm recessions. Activities of calcium and sodium from even higher discharge (above 12 $\mathrm{ft}^{3} / \mathrm{s}$ ) plot near those from the dilute waters found in springs. This indicates that the primary source of stream water at high discharge is probably overland runoff, which would also be very low in calclum and sodium. 


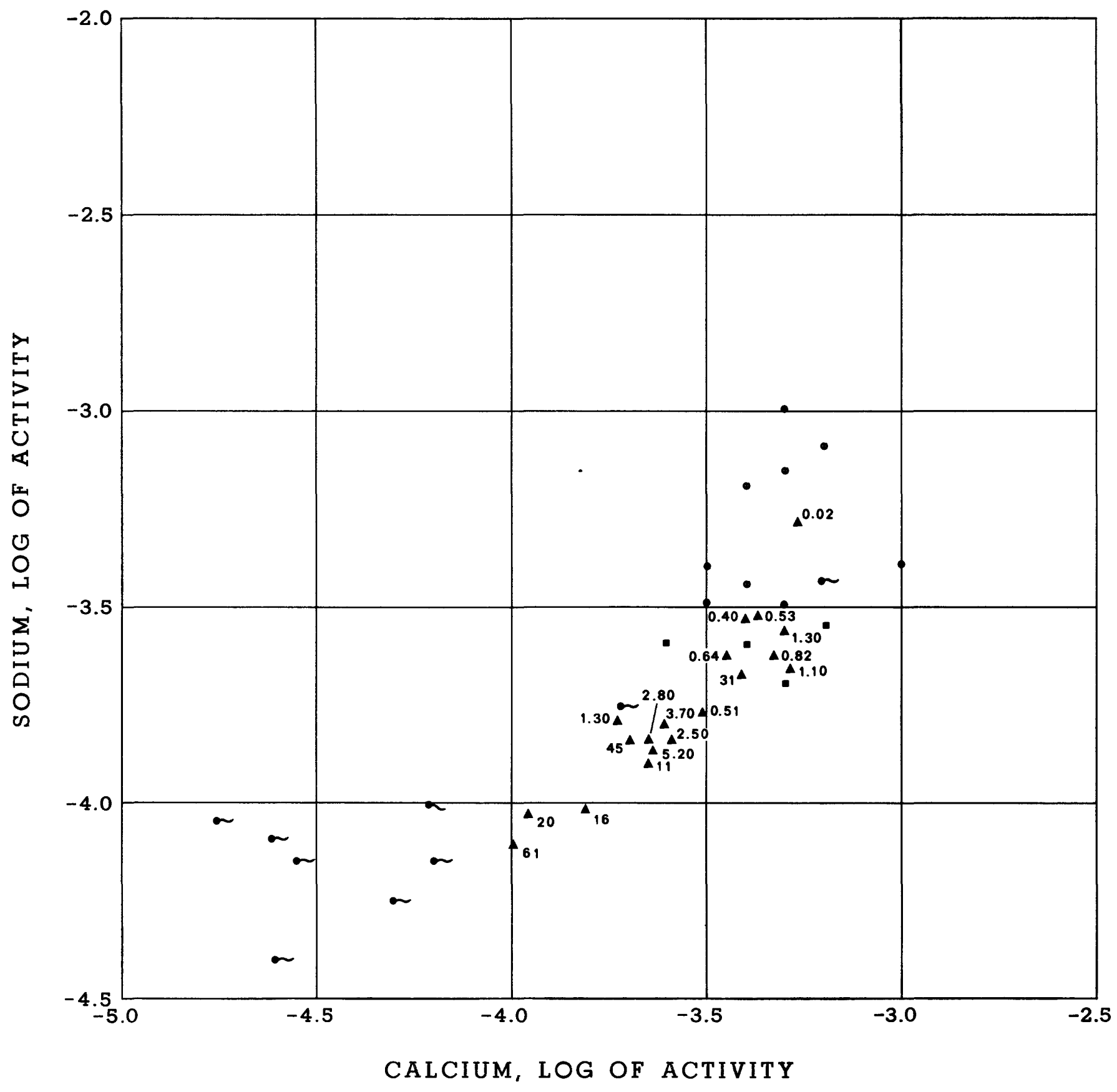

\section{EXPLANATION}

- Surface-water data

0.53 Discharge, in cubic feet per second

- Drilled well

- Dug well

$\sim$ Spring

Figure 5.2-1 -- Comparison of calcium and sodium activities for well, spring, and stream water in Grissom Creek basin. 
6.0 LTOEOGIC EFECTS OF MINING 
- 6.1 Effects of Mining on Surface Water

\title{
6.1.1 Flow duration
}

\section{Flow Duration For Russell Fork At Haysi Indicate Surface Mining Increases Base Flow}

\begin{abstract}
Flow duration curves are developed for the Russell Fork at Haysi and Clinch RIver at Cleveland covering pre-surface mining and surface-mining periods. The Russe11 Fork shows a significant increase in base flow since surface mining started, while the Clinch River, which has little mining activity in its basin, shows very little change.
\end{abstract}

Flow duration curves for the Russell Fork at Hays1 for the two periods: 1927 to 1950 (prior to any significant surface mining in the drainage basin), and 1951 to 1980 (during and after substantial surface mining within the basin), are compared in figure 6.1.1-1 along with curves for approximately the same periods for the clinch River at Cleveland. The Clinch River basin lies Immediately to the east of the Russell Fork basin and has similar climatic conditions. Many areas in the Russe11 Fork basin have been disturbed by mining activities but few areas within the Clinch River basin above Cleveland have been affected. Data from the Clinch River site were anslyzed to assess the possibility that observed changes in flow characteristics of the Russel1 Fork are due to changes in climatic conditions between the two periods. The figure shows little difference between the flow duration curves for the Clinch River in the pre-mining and post-mining periods in the basin. 


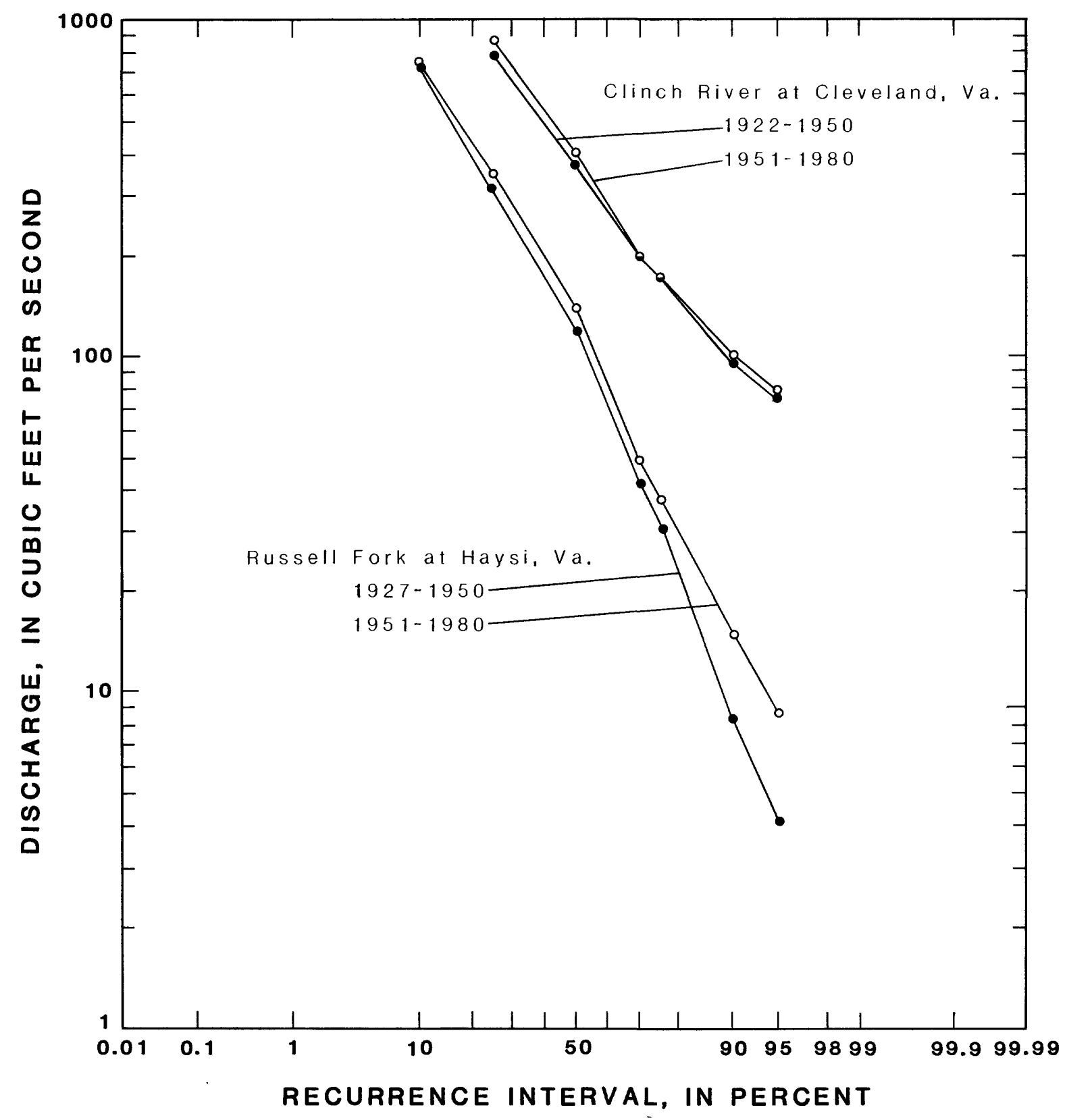

Figure 6.1.1-1 -. Flow duration curves for Russell Fork and Clinch River. 


\title{
6.1 Effects of Mining on Surface Water
}

\subsubsection{Streamflow recession}

\section{Base Flow Recession Curves Indicate That Increases \\ In Surface Mining Have Increased Ground-Water Contribution To Total Runoff}

\begin{abstract}
A base-flow recession curve from a streamflow hydrograph 18 a measure of the rate of decay of ground-water storage within a basin. Composite curves from individual recessions for the Russell Fork basin show a change in the decay rate of about 34 to 59 days per $\log$ cycle of discharge for pre-1950 and post-1950 streamflows. A comparlson of two individual recession periods starting with 1dentical discharges (Apri1 19, 1934 and March 30, 1976) illustrates the change in decay rate for the two periods of time.
\end{abstract}

Flow recession is a rate of streamflow decrease; during base-flow periods, it approximates the decay of ground-water storage in a basin. Recession curves are developed by selecting straight-line segments of stream hydrographs that show flow after storm events and transposing these segments onto a straight line through the range of discharges observed.

Figure 6.1.2-1 shows recession curves for two time periods for the Russe11 Fork gage at Haysi. Winter recession curves are used to minimize the effects of losses due to evapotranspiration. The figure shows a significant flattening of the curve during the post-1950 period and a time of 59 days per $10 \mathrm{~g}$ cycle of discharge compared to 34 days per $10 g$ cycle of discharge during the pre1950 period. This increase in decay time 18 attributed to greater storage in surface-mine spoil banks.

A technique requiring fewer data to determine the recession rate uses individual recession periods. Two nearly identical peak flows and their subsequent recessions (Apri1 19 to June 3, 1934 and March 30 to May 19, 1976) are shown in figure 6.1.2-2. The hydrographs are overlain, and a straight line is drawn through one log cycle along straight line segments of each. The time change per log cycle of discharge for the 1934 period is 36 days and for the 1976 perlod, 57 days. These values compare very closely to rate changes of 34 days and 59 days using long-term composite curves. 


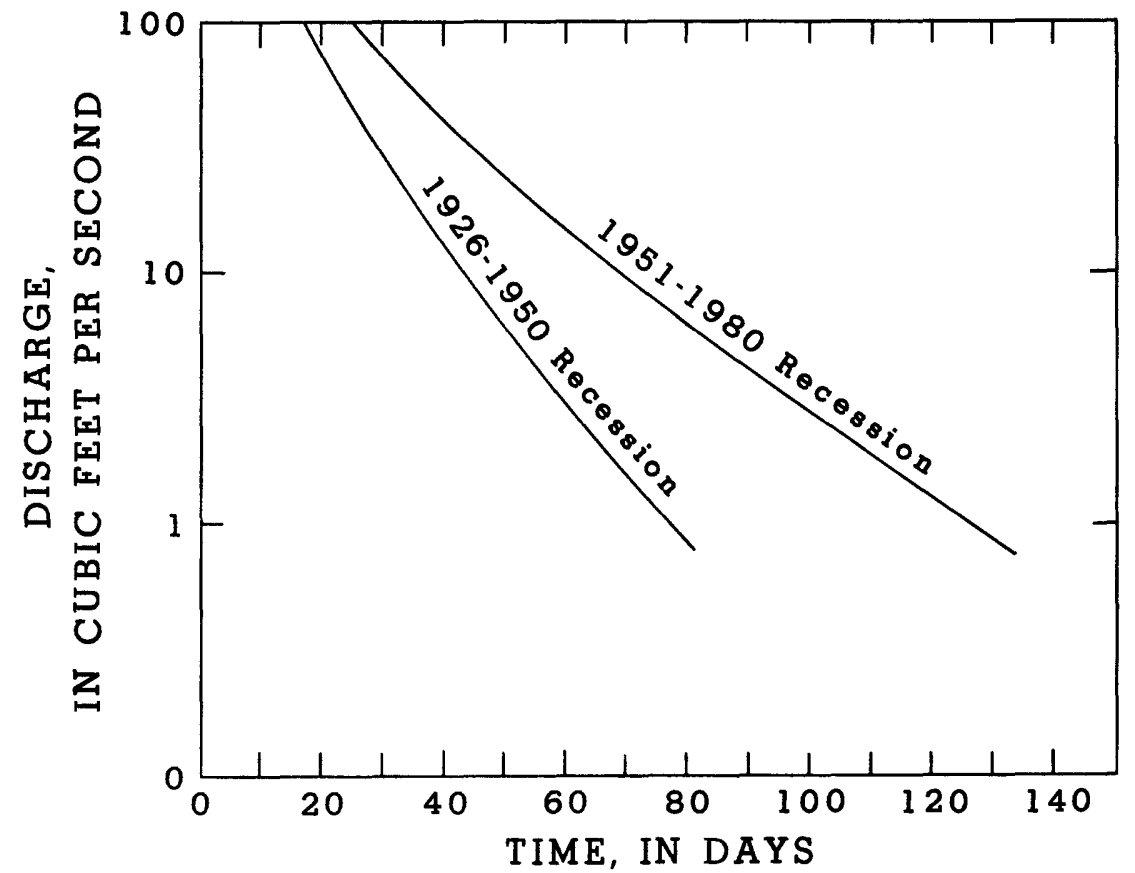

Figure 6.1.2-1 -- Composite winter recessions before and after 1950 for Russell Fork at Haysi, Va.

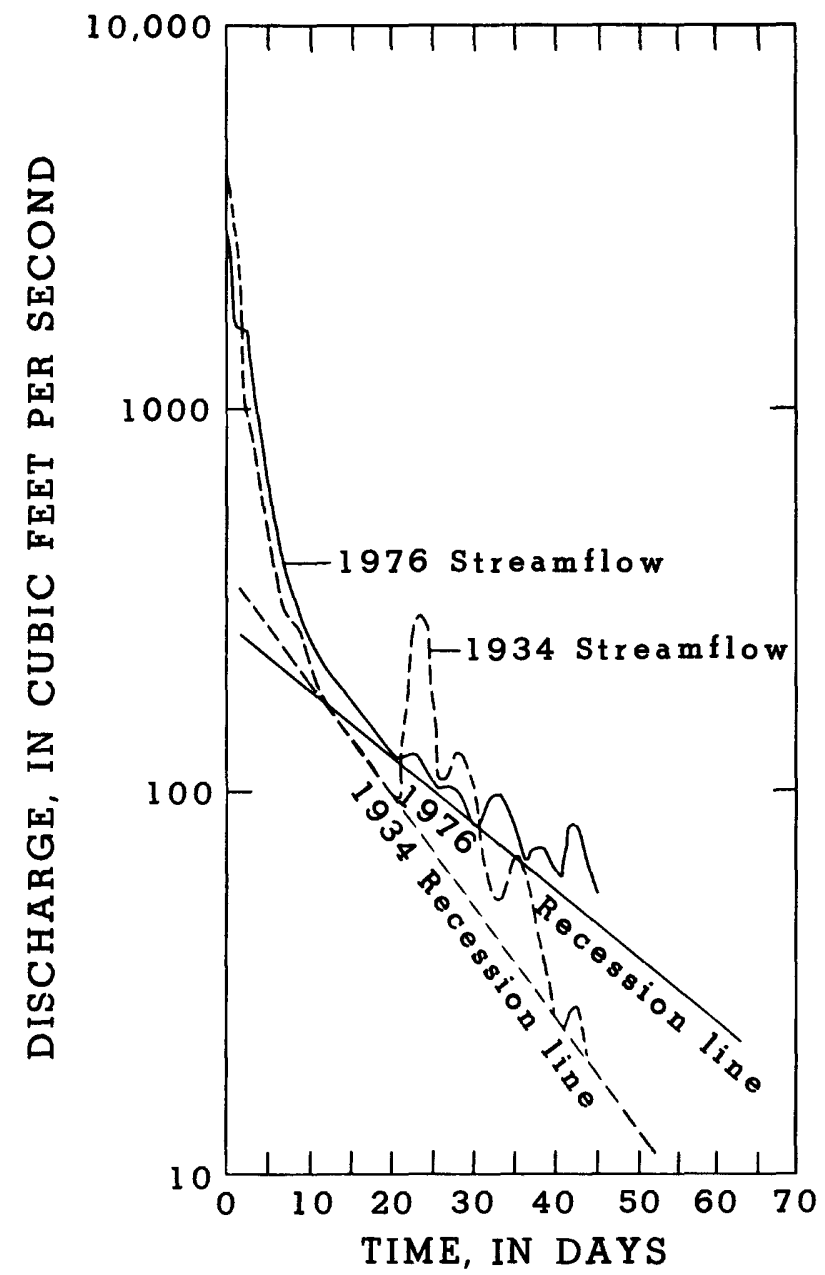

Figure 6.1.2-2 -- Streamflow recessions for Russell Fork at Haysi, Va., April 19 to June 3, 1934 and March 3 to May 19, 1976. 


\title{
6.0 HYDROLOGIC EFFECTS OF MINING (continued)
}

\subsection{Effects of Mining on Surface Water}

\subsubsection{Diffusivity}

\section{Aquifer Diffusivities Indicate A Major Hydrologic Impact OF Surface Mining}

\begin{abstract}
Aquifer diffusivities calculated for five streanflow gaging stations indicate significant changes in aquifer hydraulic properties due to surface-mining activities. Diffusivity values range from 28,500 feet squared per day ( $\mathrm{ft}^{2} / \mathrm{d}$ ) for Russell Fork at Haysi (pre-1950, with no surface mining), to $10,100 \mathrm{ft}^{2} / \mathrm{d}$ for Barton rork near Counc1l (19.5 percent of drainage area surface wined).
\end{abstract}

Aquifer diffusivities ( $T / S$ ) were determined from data at five gaging stations in the Russell Fork basin, using the Rorabaugh equation (see section 4.5). Recessions following single storm events and pre-1950 and post-1950 composite recessions based on several recession segments are used to determine diffusivity. Table 6.1.3-1 lists the physical characteristics used in the analysis of base-flow recessions and summarizes the calculated hydraulic characteristics. Diffusivity values for Russel1 Fork at Haysi declined from $27,000-28,500 \mathrm{ft}^{2} / \mathrm{d} \quad($ pre-1950) to $15,400-17,000 \mathrm{ft}^{2} / \mathrm{d}$ (post-1950).

Figure $6 \cdot 1 \cdot 3-1$ is a plot of diffusivities as a function of percentage of mined area for the five gages in the Russell Fork basin during the
Apri1 1982 base-flow recession period. Five composite and individual recessions for the Russell Fork at Haysi during selected time periods were also used. The graph shows an inverse relationship between percent of basin mined and diffusivity.

The decrease in diffusivities caused by surface mining indicates an increase in ground-water storage within the spoil material on the strip benches. The relatively flat strip benches retain precipltation for percolation into the spolls creating small ground-water reservoirs. These reservolrs slowly release the ground water in storage by seepage at the base of the spoil piles, which causes higher flows during dry periods. 
Table 6.1.3-1 - Selected physical and Hydraulic characteristics of basins above five gaging stations in the Russell Fork basin.

\begin{tabular}{|c|c|c|c|c|c|c|c|}
\hline Gaging Station & $\begin{array}{c}\text { Drainage } \\
\text { Area } \\
\text { (a12) } \\
\end{array}$ & $\begin{array}{l}\text { Surface Mine } \\
\text { Disturbance } \\
\text { (percent) }\end{array}$ & $\begin{array}{c}\text { Distance frow } \\
\text { stream to divide } \\
\text { (ft) }\end{array}$ & $\begin{array}{c}\text { Recession Per 1od } \\
\text { Anslyzed } \\
\text { (month/year) }\end{array}$ & $\begin{array}{c}\text { T1we for one } \\
\text { log cycle change } \\
\text { In discharge } \\
\text { (days) }\end{array}$ & $\begin{array}{c}\text { Diffusivity } \\
T / 8 \\
\left(f t^{2} / \text { day }\right) \\
\end{array}$ & $\begin{array}{c}\text { Time for } \\
\text { recession rate } \\
\text { to stabilize } \\
\text { (days) } \\
\end{array}$ \\
\hline $\begin{array}{c}\text { Grisso Creek } \\
\text { near Council }\end{array}$ & 2.82 & 0.0 & 1220 & $4 / 82$ & 56 & 24,800 & 11 \\
\hline $\begin{array}{l}\text { Barton Pork } \\
\text { near Counc11 }\end{array}$ & 1.23 & 19.5 & 936 & $4 / 82$ & 81 & 10,100 & 16 \\
\hline $\begin{array}{l}\text { Russe11 Fork } \\
\text { at Counc11 }\end{array}$ & 10.2 & 6.3 & 1180 & $4 / 82$ & 78 & 16,700 & 16 \\
\hline $\begin{array}{l}\text { Russell Fork } \\
\text { at Birchleaf }\end{array}$ & 86.5 & 3.9 & 1023 & $4 / 82$ & 56 & 17,400 & 11 \\
\hline $\begin{array}{l}\text { Russe11 Fork } \\
\text { at Hays1 }\end{array}$ & 286 & $\begin{array}{l}0.0 \\
0.0 \\
5.0 \\
5.0 \\
5.0\end{array}$ & $\begin{array}{l}1020 \\
1020 \\
1020 \\
1020 \\
1020\end{array}$ & $\begin{array}{c}3-5 / 34 \\
1927-1950 \\
3-5 / 76 \\
1951-1980 \\
4 / 82\end{array}$ & $\begin{array}{l}36 \\
34 \\
57 \\
59 \\
63\end{array}$ & $\begin{array}{l}27,000 \\
28,500 \\
17,000 \\
16,500 \\
15,400\end{array}$ & $\begin{array}{r}7 \\
7 \\
11 \\
12 \\
13\end{array}$ \\
\hline
\end{tabular}

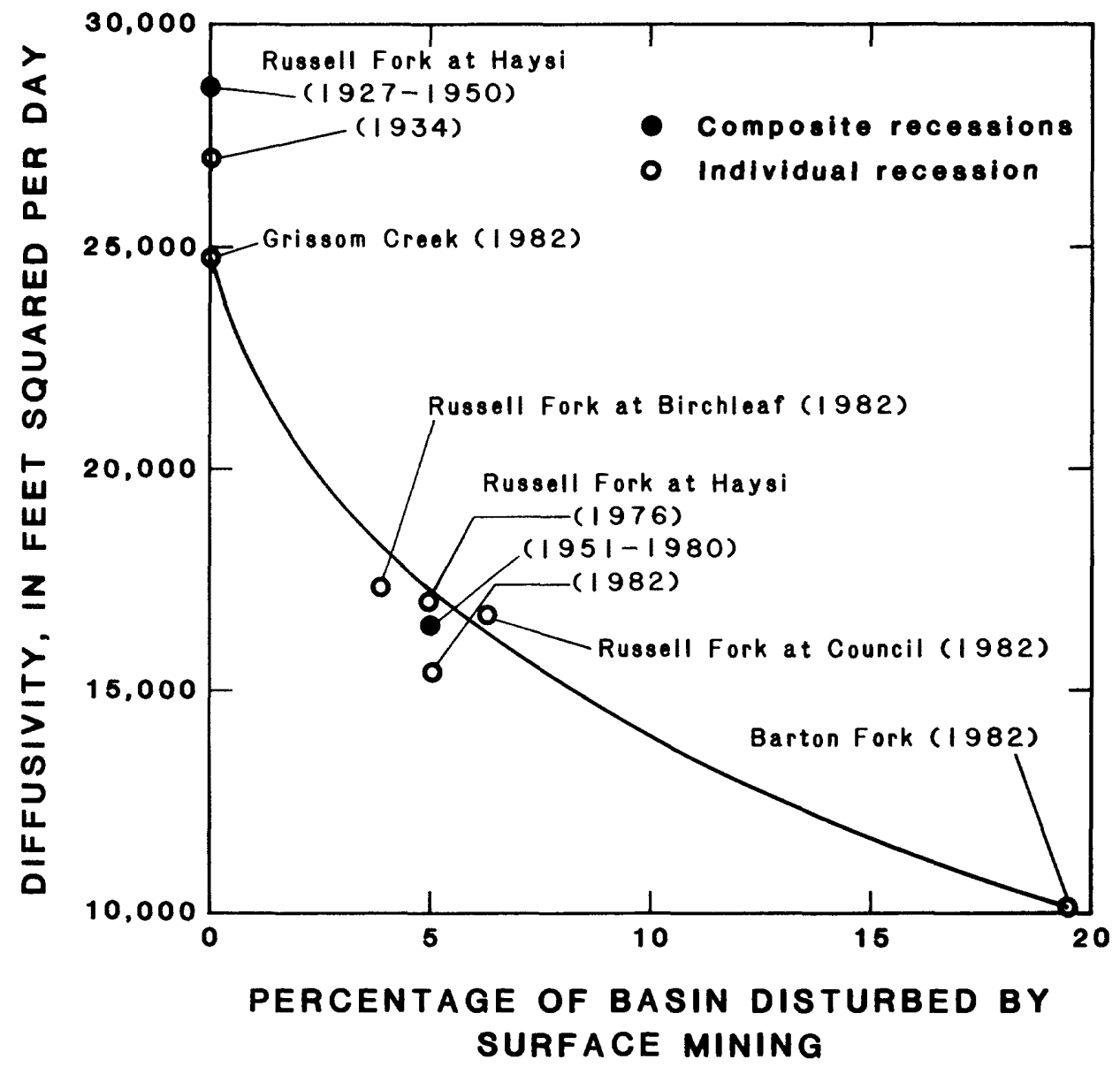

Figure 6.1.3-1 - Relation of diffusivity to extent of surface mining in the upper Russell Fork basin. 


\title{
6.0 HYDROLOGIC EFFECTS OF MINING (continued) \\ - 6.2 Effects of Mining on Ground Water
}

Surface And Underground Mining Of Coal

alter The Natural Ground-Water System

\begin{abstract}
A conceptualized ground-water flow system indicates the majority of ground-water movement is within the thin veneer of sol1, colluvium-alluvium, and weathered bedrock. Any surface-mine activity will intercept this shallow ground water and alter its natural wevent. Underground mining intercepts the small quantities of ground water moving within fractures in the unweathered bedrock. The ground water will then flow to the surface along the minedout areas or is stored in the vold left after mining.
\end{abstract}

The effects of mining on the ground-water system have been subtle but can be seen at mines in the basin. Underground mining of coal creates a drain, where water moving through the rock materials is intercepted and flows out through the mine opening. Water may also be ponded in the vold left by the coal-mining operation, which creates a subsurface storage reservoir, as shown in figure $6 \cdot 2-1$.
Surface-mine operations create large flat strip benches that act as catchment areas for precipitation. The precipitation percolates into the unconsolidated and weathered material created by the mining operation creating a ground-water reservoir. Seep areas found at the toe of strip benches are the discharge points for the ground water. Figure 6.2-2 117ustrates the ground-water flow system in a surface-mined area. 


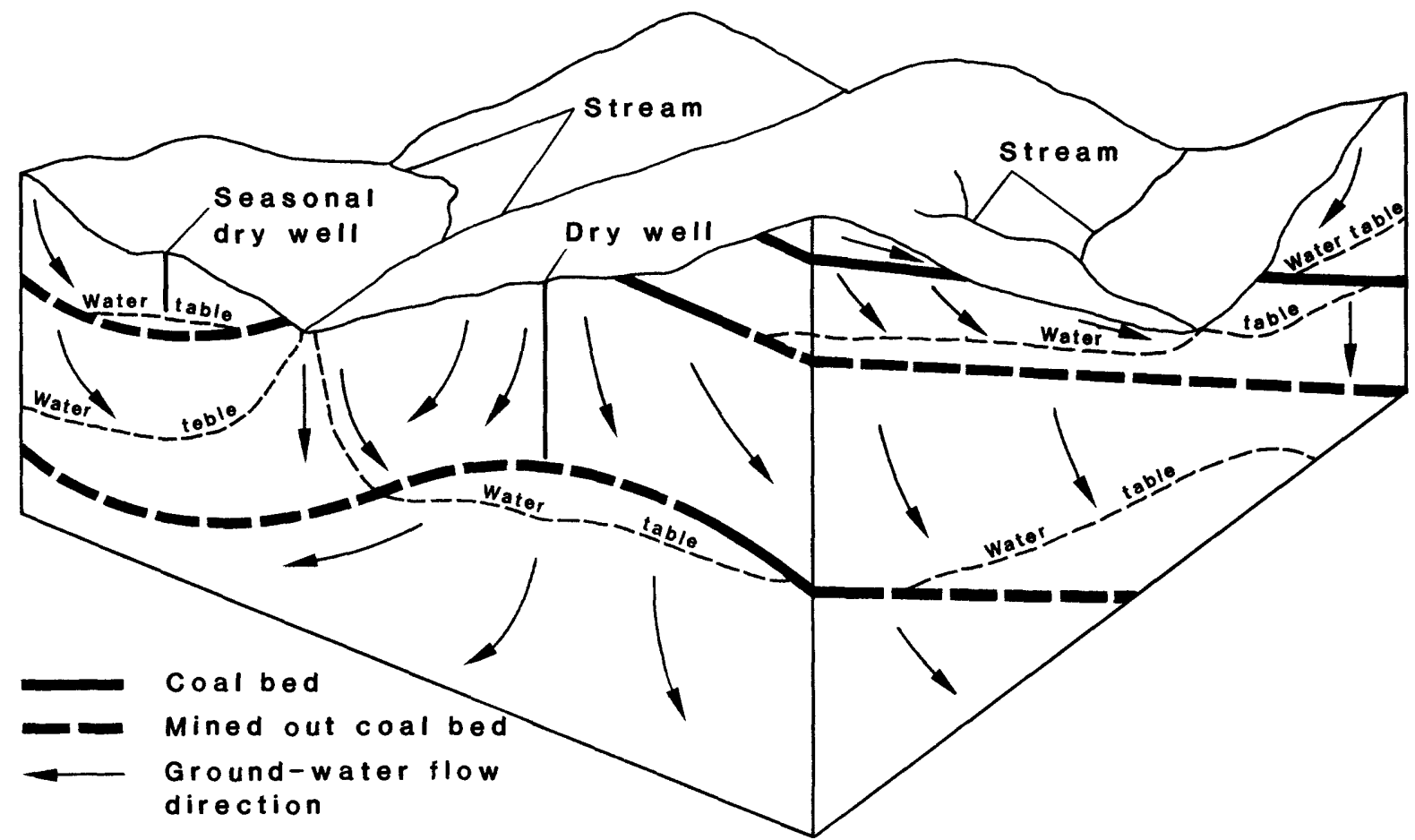

Figure 6.2-1 -- Effects of underground mining on the ground-water system.

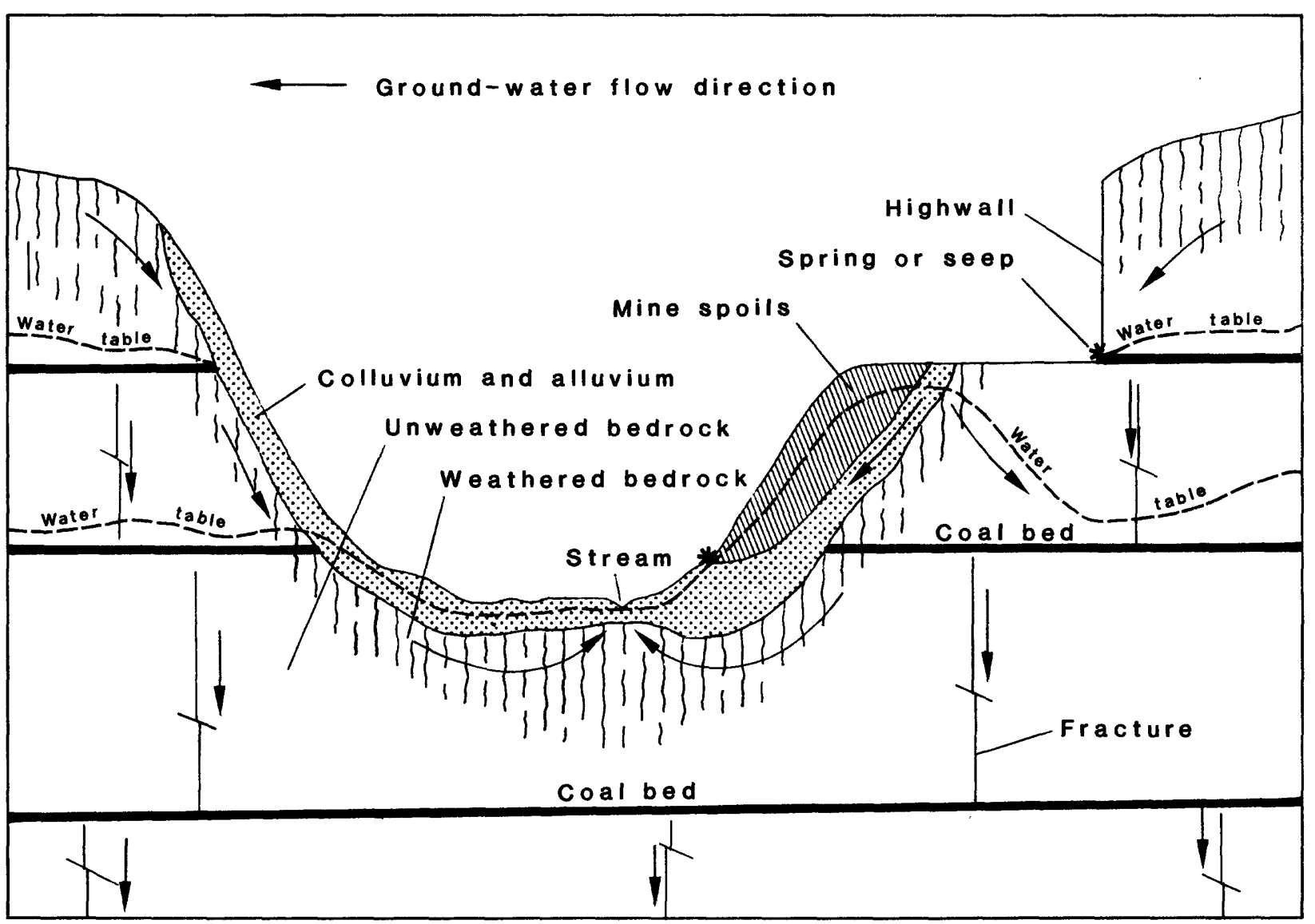

Figure 6.2-2 -- Effects of surface mining on the ground-water system. 


\subsection{SUMMARY AND CONCLUSIONS}




\section{Study Of Upper Russell Fork Basin Indicates Presence Of A Shallow Ground-Water AQuifer SYSTEM AND Significant Changes In The Hydrologic CyCle With Mining}

Results from aquifer tests conducted in the upper Russel1 Fork basin indicate that transmissivity decreases with depth. Saturated materials in the valley bottoms constitute the major aquifer system with estimated transmissivities of about $270 \mathrm{ft}^{2} / \mathrm{d}$ in alluvium, 120-140 $\mathrm{ft}^{2} / \mathrm{d}$ in the weathered bedrock zone and about $0.15 \mathrm{ft}^{2} / \mathrm{d}$ in unweathered bedrock below the valleys. Aquifer tests using ridgetop wells indicate transmissivities of about $0.3 \mathrm{ft}^{2} / \mathrm{d}$ near land surface and less than 0.01 $\mathrm{ft}^{2} / \mathrm{d}$ at a depth of 500 feet. The data suggest that most ground water moves through a shallow aquifer system, and that little water moves at depth.

Flow-duration analysis of gagingstation data indicate that base flows of streams have increased since the start of surface mining. At the 95percent flow duration, flows have increased from $4.0 \mathrm{ft}^{3} / \mathrm{s}(1928-50)$ to $8.9 \mathrm{ft}^{3} / \mathrm{s}(1951-80)$. Changes in flow duration indicate infiltration and storage of precipitation have increased and that this water drains more gradually during base-flow periods.
Analysis of a composite base-flow recession curve for the Russell Fork at Haysi gage Indicates that the time required for the stream to decline in flow through one $10 \mathrm{~g}$ cycle of discharge increased from 34 days (pre1950) to 59 days (post-1950). The slope of recession was used to calculate diffusivity. The pre-1950 diffusivity value is $28,500 \mathrm{ft}^{2} / \mathrm{d}$, and the post-1950 diffusivity is 16,500 $\mathrm{ft}^{2} / \mathrm{d}$.

Individual recession perlods were analyzed at five gaging stations in the basin. Diffusivities obtained varied from $27,000 \mathrm{ft}^{2} / \mathrm{d}$ for Russell Fork at Haysi before major surfacemining activities started, to 10,100 $\mathrm{ft}^{2} / \mathrm{d}$ for Barton Fork near Counc11, which has 19.5 percent of its area disturbed by surface mining.

Coal mining affects ground-water and surface-water quality. Sulfate concentrations are higher in mined basins than in unmined basins. The sulfate concentrations in surface water within a mined area are greater at high flow when water is most dilute than in an unmined basin at low flow when concentrations of constituents are highest. 


\subsection{SELECTED REFERENCES}

61 
Barr, A. J., Goodnight, J. H., Sall, J. P., Helwig, J. T., 1976, Statistical analysis system: SAS Institute Inc., Raleigh, N.C., 329 p.

Boulton, N. S., 1963, Analysis of data from non-equilibrium pumping tests allowing for delayed yield from storage: Institute of Civil Engineers Proceedings (London), v. 26 , p. 469-482.

Cooper, H. H., Jr., and Jacob, C. E., 1946, A generalized graphical method for evaluating formation constants and summarizing wellfleld history: American Geophysical Union Transactions, v. 27, no. 4, p. 526-534.

Cooper, H. H., Jr., Bredehoeft, J. D., and Papadopulos, I. S., 1967, Response of a finite-diameter we11 to an instantaneous charge of water: Water Resources Research v. 3, no. 1, p. 263-269.

Daniel, J.F., 1976, Estimating groundwater evaporation from streamflow records: Water Resources Research, v. 12 , no. 3 , p. 360-264.

Englund, K. J., 1971, Displacement of the Pocahontas Formation by the Russel1 Fork fault, southwest Virginia: U.S. Geological Survey Professional Paper 750-B, p. B13B16.

Epps, S. R., 1978, Buchanan County groundwater: Virginia state Water Control Board Planning Bulletin No. 311 .

Ferris, J. G., and Knowles, D. B. 1954, Slug test for estimating transmissibility: U.S. Geological Survey Ground Water Note 26 .
Ferris, J. G., Knowles, D. B., Brown, R. H., and Stallman, R. W., 1962, Theory of aquifer tests: U.S. Geological Survey Water-Supply Paper 1536-E, p. 69-174.

Ha11, F. R., 1968, Baseflow recession --review: Water Resources $\mathrm{Re}^{-}$ search, 4, p. 973-983.

Hely, A. G., and Olmsted, F. H., 1963, Some relation between streamflow characteristics and the environment in the Delaware River region: U.S. Geological Survey Professional Paper 417-B, p. B1-B25.

Jacob, C.E., 1943, Correlation of ground-water levels and precipitation on Long Island, New York: American Geophysical Union Transactions, v. 24, pp. 564-573.

Lohman, S. W., 1979, Groundwater hydraulics: U.S. Geological Survey Professional Paper 708.

Meissner, C. R., Jr., 1978, Geologic map of the Duty quadrangle, Dickenson, Russell and Buchanan counties, Virginia: U.S. Geological Survey Geologic Quadrangle Map GQ-1458, scale 1:24000.

Miller, R.L., and Meissner, C.R., Jr., 1977, Geologic map of the Big A Mountain quadrangle, Buchanan and Russell Counties, Virginia: U.S. Geological Survey Geologic Quadrangle Map GQ-1350, scale $1: 24000$.

Riggs, H. C., 1964, The base-flow recession curve as an indicator of ground water: International Association of Sclentific $\mathrm{Hy}-$ drology Publication 63, p. 352363 . 
1968a, Some statistical tools In hydrology: U.S. Geological Survey Techniques of WaterResources Investigations book 4, Chap. Al, 39 p.

1973, Regional analysis of streamflow characteristics: U.S. Geological Survey Techniques of Water-Resources Investigations, Book 4, Chapter B3, 15 p.

Rogers, S. M. and Powell, J. D., 1983, Quality of ground water in southern Buchanan County, Virginia: U.S. Geological Survey Water-Resources Investigation $82-4022,36$ p.

Rorbaugh, M. I., 1960, Use of water levels in estimating aquifer constants: International Association of Scientific Hydrology, Publication 52, p. 314-323.

, 1964, Estimating changes in bank storage and ground-water contribution to streamflow: International Association of Scientific Hydrology, Publication 63, p. 432441 . and Simons, W.D., 1966, Exploration of methods of relating ground water to surface water, Columbia River basin-second phase: U.S. Geological Survey Open-File Report, 62 p.

Searcy, James K., 1959, Flow-duration curves: U.S. Geological Survey Water Supply Paper 1542-A.

Stallman, R. W., 1963, Electric ana$\log$ of three dimensional flow to wells and its application to unconfined aquifers: U.S. Geological Survey Water-Suppy Paper $1536 \mathrm{H}, 38 \mathrm{p}$.

, 1965, Effects of water-table conditions on water-level changes near pumping wells: Water $\mathrm{Re}^{-}$ sources Research, v. 1, no. 2, p. 295-312. 